\title{
Geochemistry of Platinum-Group Elements (PGE) in Cerro Matoso and Planeta Rica Ni-Laterite deposits, Northern Colombia
}

\author{
Geoquímica de los Elementos del Grupo del Platino (EGP) en los depósitos lateríticos de Ni de Cerro \\ Matoso y Planeta Rica, Norte de Colombia
}

\author{
Mónica Tobón ${ }^{1, *}$, Marion Weber ${ }^{1}$, Joaquín A. Proenza², Thomas Aiglsperger ${ }^{3}$, \\ Sebastián Betancur ${ }^{1}$, Júlia Farré-de-Pablo², Carlos Ramírez ${ }^{1}$, Núria Pujol-Solà2
}

\begin{abstract}
Departamento de Materiales y Minerales, Facultad de Minas, Universidad Nacional de Colombia, Carrera 80 \# 65-223, Medellín, Colombia
\end{abstract}

\begin{abstract}
Departament de Mineralogia, Petrologia i Geologia Aplicada, Universitat de Barcelona (UB), Martí i Franquès s/n, 08028 Barcelona, Spain.

${ }^{3}$ Luleå University of Technology, Department of Civil Engineering and Natural Resources, Division of Geosciences and Environmental Engineering, SE 97187 Luleå, Sweden.
\end{abstract}

* Corresponding author: (M. Tobón) mjtobon@unal.edu.co

\begin{abstract}
Platinum-group elements (PGE) are included among the so-called critical metals, and are essential metals for the technological industry. However, there are very few deposits in the world from which these metals can be extracted. The present work investigates three Ni-laterite profiles (hydrous $\mathrm{Mg}$ silicate type) formed over the ultramafic rocks of Cerro Matoso and Planeta Rica in Colombia. The main goal is to determine their PGE concentration and distribution, as well as to identify the carrier phases of these noble metals. The highest PGE contents in Cerro Matoso and Planeta Rica are concentrated in the limonite horizon (141-272 ppb), showing a strong decrease towards the saprolite and the underlying serpentinized peridotite (parent rock; $<50 \mathrm{ppb}$ ). The highest concentrations correspond to $\mathrm{Pt}>\mathrm{Ru}>\mathrm{Pd}$ and the lowest to $\mathrm{Rh}<\mathrm{Os}_{\mathrm{s}}<\mathrm{Ir}$. Such distribution indicates that PGE are mobilized in different proportions by the laterization processes. The high affinity between PGE and Fe favors the formation of PGE-Fe mineral alloys such as the Pt-Ir$\mathrm{Fe}-\mathrm{Ni}$ minerals hosted by Fe-oxyhydroxide found in the limonite-saprolite transition zone in Planeta Rica. In addition, in the same zone, nanoparticles of $\mathrm{Pt}(<1 \mu \mathrm{m})$ were found within framboidal pyrite. Both types of platinum group minerals (PGM) are secondary in origin. In the case of Pt-Ir$\mathrm{Fe}-\mathrm{Ni}$ alloys, this interpretation is supported by their morphology and chemical composition, which is comparable with PGE-Fe-Ni alloys found in laterites of Dominican Republic. In the case of Pt nanoparticle, textural relations suggest the neoformation of PGM adhered to the porous edges of altered pyrite. Cerro Matoso and Planeta

\section{RESUMEN}

Los elementos del grupo del platino (EGP) están incluidos entre los denominados metales críticos y son esenciales en la industria de productos tecnológicos. Sin embargo, existen muy pocos depósitos de los cuales puedan ser extraídos. Este trabajo investiga tres perfiles de laterita de $\mathrm{Ni}$, tipo silicato hidratado, desarrollados sobre las rocas ultramáficas de Cerro Matoso y Planeta Rica en Colombia. El objetivo principal es determinar la concentración y distribución de EGP, así como identificar las fases portadoras de estos metales. Los mayores contenidos de EGP en Cerro Matoso y Planeta Rica, se concentran en el horizonte limonítico (141-272 ppb) y muestran una fuerte disminución hacia la zona saprolítica y la peridotita serpentinizada (roca parental; $<50$ ppb). Las concentraciones más altas corresponden a $P t>R u>P d$ y las más bajas a $R h<O_{s}<I$ r. Esta distribución indica que los EGP son movilizados en proporciones diferentes durante los procesos de laterización. La alta afinidad entre los EGP y el Fe favorece la formación de aleaciones de EGP-Fe tales como Pt-Ir-Fe-Ni hospedados en oxi-hidróxidos de Fe encontrados en la zona de transición limonita-saprolita en Planeta Rica. Además, se encontraron en la misma zona nanopartículas de $P t(<1 \mu \mathrm{m})$ dentro de pirita framboidal. Ambos tipos de minerales del grupo del platino (MGP) son de origen secundario. En el caso de las aleaciones $P t-I r-F e-N i$, esta interpretación está sustentada por su morfología y composición química, comparable con las aleaciones de PGE-Fe-Ni encontradas en las lateritas de República Dominicana. En el caso de las nanopartículas de Pt, las relaciones texturales sugieren la neoformación de MGP adheridos a los bordes porosos de pirita alterada. Con todo esto, Cerro Matoso y Planeta Rica deberían ser considerados como potenciales depósitos no convencionales de EGP, si se aplicasen procesos de refinación adecuados para su recuperación como subproductos durante la producción de $\mathrm{Ni}(+\mathrm{Co})$.
\end{abstract} Rica should be considered as unconventional PGE deposits, if adequate recovery processes can be applied for their recovery as by-products during $\mathrm{Ni}(+\mathrm{Co})$ production.

Keywords: Ni-laterite deposit, platinum group elements (PGE), platinum group minerals (PGM), Gerro Matoso, Planeta Rica, Colombia.
Palabras clave: Depósito de laterita de Ni, elementos del grupo del platino (EGP), minerales del grupo del platino (MGP), Cerro Matoso, Planeta Rica, Colombia. 


\section{Introduction}

Platinum-group elements (PGE), osmium (Os), iridium (Ir), ruthenium $(\mathrm{Ru})$, rhodium $(\mathrm{Rh})$, platinum $(\mathrm{Pt})$, and palladium $(\mathrm{Pd})$, are considered high-tech metals due to their physical and chemical characteristics. Their most prominent use is as catalytic converters, which decrease polluting emissions from automobiles. They are also used in electronic applications, jewelry, and laboratory equipment (Lusty, 2016; EC, 2018; USGS, 2018). Therefore, there is a high demand for platinum group minerals (PGM) both in the national and international markets. For this reason, they were included among the list of strategic minerals in Colombia. Since then, efforts are being made in order to identify areas from which they can be mined in a sustainable way, thus helping to promote the economic and social development of the country (Ministerio de Minas y Energía, 2012a).

PGE deposits with economic significance are very rare worldwide (e.g. Holwell and McDonald, 2010). The main typical sources of these metals occur in three major geological environments: i) Low-S layered intrusion-hosted, e.g. Bushveld and Great Dyke (South Africa) and Stillwater (USA); ii) High-S magmatic Ni-Cu sulfide deposits, e.g. Noril'sk-Talnakh (Russia); and iii) PGE placer deposits from Alaskan-type ultramafic intrusions, e.g. Urals (Russia) and Zoned Ultramafic Alto Condoto Complex (CUZAC, by its acronym in Spanish) in Colombia. However, there are also the so-called unconventional PGE deposits, which allow PGE exploitation on a minor scale. Among these, we find PGE deposits in ophiolites (e.g. Troodos, Cyprus; Ray Iz, Russia; Shetlands, UK), and lateritic profiles in ultramafic rocks (e.g. Weld Range, Western Australia; Syerston, Southeastern Australia) (Green and Peck, 2005).

Recent studies have found that weathering processes in ultramafic rocks enable residual and secondary enrichment of PGE (Aiglsperger et al., 2015, 2016a; Proenza, 2015). Changes in Eh-pH conditions and microbiotic activity, as well as the presence of organic matter, favor the mobility, re-precipitation, and concentration of $\mathrm{PGE}$ in the upper levels of the laterite profile (Bowles, 1986; Augé and Legendre, 1994; Bowles et al., 1994a, 1994b; Wilde et al., 2003; Proenza et al., 2004; Aiglsperger et al., 2015, 2016a, 2016b). As a consequence, countries such as New Caledonia, Greece, Cuba, the Dominican Republic, and Australia have shown interest in their PGE potential and several studies have been performed in order to evaluate it. For instance, laterites from the New Caledonia ophiolitic complex (Pirogues zone) exhibits Pt values up to 2 ppm (Augé and Legendre, 1994). The Fe-Ni laterites of Greece show mean values of $\mathrm{Pt}$ and $\mathrm{Pd}$ of 44 and $29 \mathrm{ppb}$, respectively, and maximum values of $88 \mathrm{ppb} \mathrm{Pt}$ and $186 \mathrm{ppb}$ Pd (Eliopoulos and Economou-Eliopoulos, 2000). The Falcondo Ni-laterite deposit in the Dominican Republic has a total PGE content ranging from $36 \mathrm{ppb}$, in the parental rock, to $640 \mathrm{ppb}$ in the limonite horizon (Aiglsperger et al., 2015; Proenza, 2015). The Owendale lateritic deposit, developed over an Alaskan-type ultramafic-mafic complex in Australia, has measured mineral resources of 105 koz of Pt (Platina Resources Limited, 2019).

In Colombia, Pt has been extracted since the beginning of the $20^{\text {th }}$ century from the alluvial deposits located in the tributaries of the San Juan, Atrato, and Condoto rivers of the Chocó Department (Leal León, 2009). These deposits were originated in Alaskan-Type CUZAC and, nowadays, these areas continue to represent the main potential for Pt exploitation in the country (SGC, 2011; Ministerio de Minas y Energía, 2012b; ANM, 2015). A study published by Ortiz et al. (2004) about precious metals (Au, Ag and PGE) in Colombia, including the Medellín Metaharzburgitic Unit, Cerro Matoso, and El Roble massive sulfide deposit, identifies unexplored potential in these units and deposits. Values of $\sim 6.4 \mathrm{ppm} \mathrm{Au}$ and $3.6 \mathrm{ppm} \mathrm{Ag}$ were detected in the magnetic canga of Cerro Matoso; up to $874 \mathrm{ppb} \mathrm{Pt}, 810$ ppb Pd, and 54 ppb Au in the Medellín Metaharzburgitic Unit; and an average of 3 ppm Au and up to 39 ppm Ag in El Roble. 
The purpose of this paper is to analyze, for the first time, the occurrence and distribution of PGE in laterites formed over ultramafic rocks in Colombia, specifically the Cerro Matoso and Planeta Rica ultramafic units. We focused our research on two Ni-laterite deposits, investigating how weathering processes on ultramafic rocks favor residual and secondary enrichment of PGE in the uppermost levels of the weathering profile (limonite horizon). The studied deposits are two of the six nickel deposits recognized in Colombia: the Cerro Matoso S.A. mine (operated by South32 Ltd.) being the most important and the only Ni-laterite deposit exploited in the country (Castro, 1987; UPME, 2009), and the deposit of Planeta Rica, which is the second most important economic prospect of Ni-laterite after Cerro Matoso.
Cerro Matoso deposit is one of the world's major producers of ferronickel alloy, with a production of $41.1 \mathrm{kT}$ in FY19 (South32, 2019). The mine has been exploited since 1982 and it is expected to continue for 10 years more, given that it has a total ore reserve of $32 \mathrm{Mt}$ and $312 \mathrm{Mt}$ in mineral resource (South32, 2019). Although the deposit of Planeta Rica is considered as the second most important source of Ni-laterite after Cerro Matoso, only exploratory work has been carried out to this day in the area. The mining title of Planeta Rica deposit also belongs to Cerro Matoso S.A., which, in the last 5 years, conducted drilling campaigns in order to determine its mineral resources. The company has not yet made available a public a report of the resources found, and the only available report so far is from the United Nations, pub-

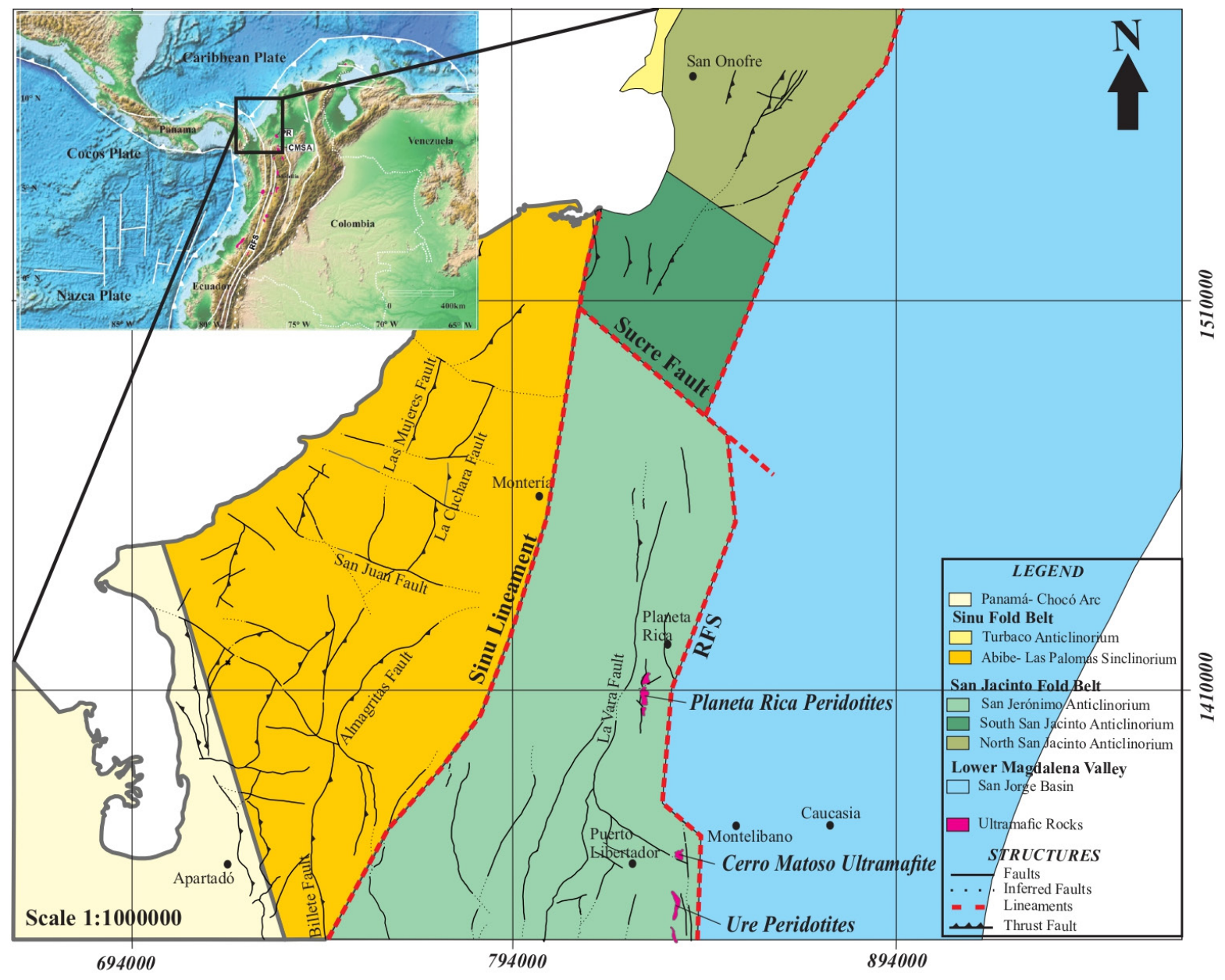

Figure 1 Location and geological map of the study areas corresponding to the Planeta Rica Peridotites and the Cerro Matoso Ultramafic Unit. Modified after Geotec Ltda. (2003); Guzmán et al. (2004); Gómez et al. (2015); and Mora et al. (2017). 
lished in 1975. This report calculated Ni reserves of 5.2 Mt on a dry basis, and concluded that a mining project was not economically feasible. The results of our research will favor the identification of new unconventional exploration targets of $\mathrm{Pt}$ in Colombia and will also serve as an example of PGE occurrence in Ni-laterites.

\section{Geological setting}

The Meso-Cenozoic tectonic evolution of the Northern Andes is characterized by the interaction of the South American continental margin with a series of allochthonous terranes of oceanic affinity, which were accreted diachronously along different segments of the continental margin and subsequently fragmented and dispersed along transcurrent fault systems during the Cenozoic (Toussaint, 1996; Ramos and Aleman, 2000; Cediel et al., 2003; Villagómez, 2010; Bayona et al., 2012; Spikings et al., 2015; Mora et al., 2017).

The geographic configuration of the Colombian territory is mainly made up of three mountains ranges (Western, Central, and Eastern), inter-mountain valleys (Cauca and Magdalena), and recent alluvial plains. The tectonic configuration of the western margin of the Northern Andes is limited by a suture, known regionally as the Romeral Fault System (RFS). The RFS demarcates the collision of oceanic units to the west and continental units to the east, and is defined by the presence of dispersed ultramafic rocks (Cediel et al., 2003; Villagómez, 2010; Spikings et al., 2015; Mora et al., 2017). The origin of these ultramafic rocks may be associated with different oceanic elements formed in environments of MOR (e.g. Bartok et al., 1985), intra-oceanic island arcs (e.g. Nivia et al., 1996; Spadea and Espinosa, 1996), and the Caribbean Plateau (e.g. Millward et al., 1984; Nivia, 1996; Kerr et al., 1997). The ultramafic rocks of Cerro Matoso and Planeta Rica are located in this suture zone, between the structural unit called the San Jacinto Fold Belt (SJFB) and the San Jorge Basin of the Lower Magdalena Valley (LMV) in northern Colombia (Figure 1).
The SJFB is limited to the east by the San Jorge Basin and to the west by the Sinu Lineament. It is made up of three anticlinorium structures: San Jerónimo, San Jacinto, and Luruaco (DuqueCaro, 1980; González and Londoño, 2001; Geotec Ltda, 2003; Guzmán et al., 2004). They comprise marine sediments with terrigenous influence which were deposited in a fore-arc environment and later accreted to the northern margin of Colombia during the Eocene (Villagómez, 2010; Mora et al., 2017): the Upper Cretaceous Cansona Formation, the Upper Paleocene to Lower Eocene San Cayetano Formation, and the Middle to Upper Eocene Chengue and San Jacinto Formations. Based on $\mathrm{U} / \mathrm{Pb}$ geochronology and Hf-isotopes on detrital zircons, Mora et al. (2017) suggested that the San Cayetano and Chengue/ San Jacinto sequences represent Late Cretaceous oceanic and continental magmatic arcs, respectively.

\subsection{GERRO MATOSO ULTRAMAFIC UNIT}

The Cerro Matoso Ultramafic Unit is located at the southwest of Montelíbano, Colombia, and it outcrops as an oval-shaped hill trending NW. It covers an area of $\sim 425$ ha and it had a maximum height of 252 m.a.s.l. before mining began (López-Rendón, 1986; Hoyos and Velázquez, 1996; González and Londoño, 2001) (Figure 2). The ultramafic unit corresponds to a partially serpentinized harzburgite (Mejía and Durango, 1982; López-Rendón, 1986; Gleeson et al., 2004) that underlies discordantly the sediments of the Pliocene Cerrito Formation and recent alluvial deposits (Hoyos and Velázquez, 1996; Gómez et al., 2015). According to some geological models, its emplacement took place during the pre-Andean orogeny (Middle Eocene) and, from that moment, the laterization process began (Dueñas and Duque-Caro, 1981; López-Rendón, 1986; Hoyos and Velázquez, 1996), reaching an average laterite profile thickness of $48 \mathrm{~m}$ (Mejía and Durango, 1982; López-Rendón, 1986) and a maximum height of 146 m (López-Rendón, 1986). 
Based on the mineralogy of the main $\mathrm{Ni}$ ores, the Cerro Matoso Ni-laterite deposit has been classified as hydrous silicate-type (Brand et al., 1998; Gleeson et al., 2003; Freyssinet et al., 2005). The lateritic profile of Cerro Matoso is characterized by seven horizons (Gleeson et al., 2004), which, from top to bottom, are:

1) Canga, which can be divided into two types: a) a dark red horizon, extremely hard, strongly magnetic, and dominated by maghemite and minor amounts of goethite; and b) a nodular canga, non-magnetic, with a major proportion of gibbsite;

2) Red laterite: a red-brown, very soft, fine-grained horizon devoid of any feature of the original rock fabric; it is very rich in Fe-oxides and goethite, and also contains small amounts of smectite;

3) Yellow laterite: a silt- to clay-grained horizon dominated by quartz and smaller amounts of Fe-oxides and goethite;

4) Black saprolite: a dark green to black interval associated with tachylite and fault zones, domi- nated by Fe-oxides, sepiolite, smectite, and quartz;

5) Brown saprolite: an orange-brown horizon, with grain size ranging from fine sand to silt, containing some rare remnants of the protolith and with a high content of sepiolite, serpentine, and quartz;

6) Green saprolite: the main Ni-ore horizon, green, fine-grained and soft; its mineralogy is dominated by sepiolite, pimelite, quartz, Fe-oxides, Ni-rich serpentine, with minor siderite-magnesite;

7) Saprolitized peridotite and peridotite (unweathered rock): made up of forsteritic olivine, serpentine, enstatite, and chromite.

An additional horizon can be found at Cerro Matoso. This horizon is atypical and not completely understood, originally misnamed as "tachylyte". It is a dark-brown to black horizon, very fined-grained, with glassy texture, and made up of amorphous phases and Fe-oxides associated to fault zones within the deposit.

The Cerro Matoso mine is divided into two major exploitation mining areas: Pit 1 and Pit 2.
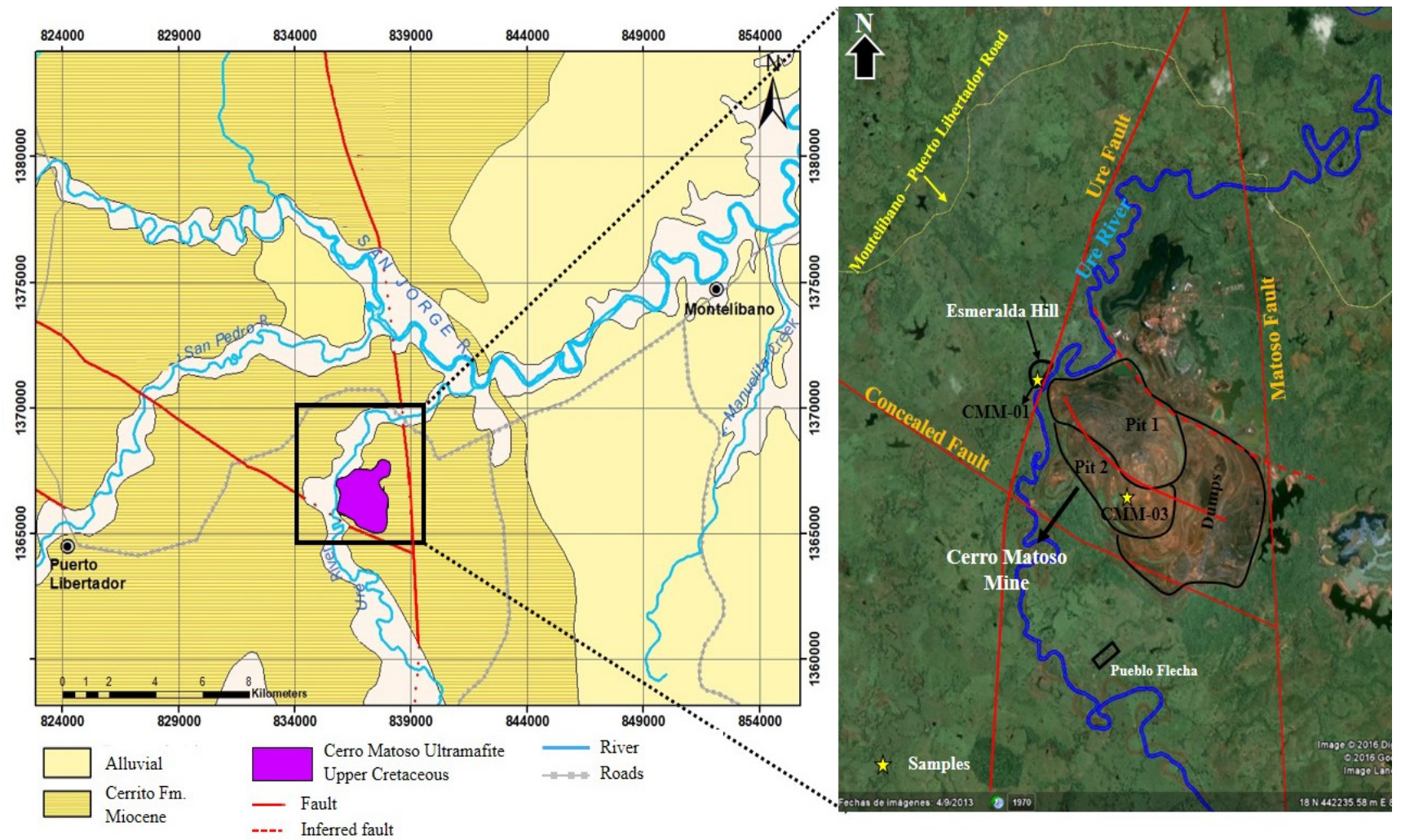

Figure 2 Left: Local geology of Cerro Matoso modified after Gómez et al. (2015). Right: Satellite image (Google Earth) showing the Cerro Matoso mine, with the location of the studied samples and the approximate location of the extraction pits and dumps (Modified after Londoño and González,1997; Gleeson et al., 2004; and Gómez et al,. 2015). 


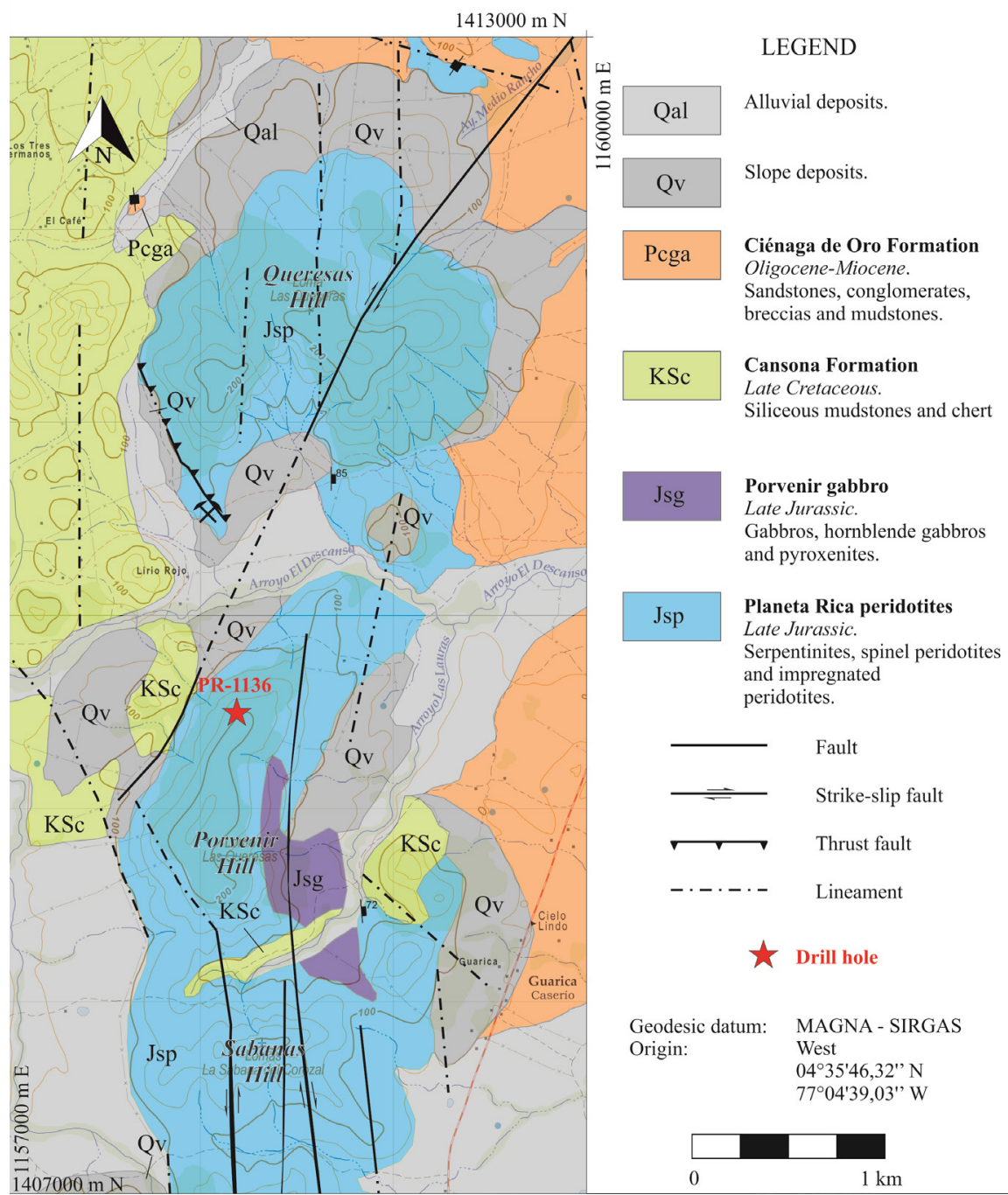

Figure 3 Geological map of the Planeta Rica area with the location of the PR-1136 drill hole. Modified after Ramírez et al. (2019).

These two pits exhibit characteristic weathered profiles as described below (Gleeson et al., 2004):

a) The Pit 1 profile has the highest Ni-grade, concentrated in four major Ni-bearing phases: pimelite, sepiolite, nimite, and $\mathrm{Ni}$-smectites. It is characterized by a canga zone at the top of a sequence composed of red laterite, black saprolite, tachylite, green saprolite, saprolitized peridotite, and peridotite.

b) The Pit 2 profile has a lower Ni concentration. The mineral assemblage is dominated by Fe-oxyhydroxides, clays, and quartz, and it is characterized from top to base by red laterite, yellow laterite, brown saprolite, saprolitized peridotites, and peridotites.
At present, the Cerro Matoso Ni-laterite deposit has considerably decreased its thickness to an average of $10 \mathrm{~m}$, and the most common sequences consists of: 1) red laterite - green saprolite - saprolitized peridotite - peridotite; 2) green saprolite - saprolitized peridotite - peridotite; 3) red laterite - saprolitized peridotite - peridotite; and 4) peridotite (unweathered rock).

\subsection{PLANETA RIGA PERIDOTITES}

The Planeta Rica Peridotites crop out to the north of Cerro Matoso (Figure 1), and comprise three isolated hills; Queresa, Porvenir, and Sabana (Naciones Unidas, 1975), located near the Pla- 
neta Rica town in northwestern Colombia. The unit has an elongated shape, with a maximum extent of $10 \mathrm{~km}$ in the $\mathrm{N}-\mathrm{S}$ direction. The rock assemblage is mainly made up of serpentinites and highly serpentinized and sheared peridotites (Naciones Unidas, 1975; Dueñas and DuqueCaro, 1981). On Porvenir hill the peridotites are intruded by the Porvenir Gabbro unit, composed of gabbros, hornblende gabbros, and pyroxenites. Both units correspond to a supra-subduction zone (SSZ) ophiolite of Late Jurassic age (Ramírez et al., 2019). The Planeta Rica Peridotites are overlaid by Late Cretaceous marine layers from the Casona Formation. These marine layers are composed by chert, siliceous mudstone, sandstones and limestones alternated with basaltic lavas (Naciones Unidas, 1975; Dueñas and Duque-Caro, 1981). These lavas are genetically associated with the Nuevo Paraíso Basalts, which outcrop to the south of the studied area (Ramírez et al., 2019) (Figure 3).

The Planeta Rica Ni-laterite deposit has been less studied than the Cerro Matoso deposit. However, sub-economic mineral resources were measured for the Ni-laterites found in the Queresa and Porvenir hills (Naciones Unidas, 1975). Naciones Unidas (1975) reported a thickness of 8 to 10 meters of laterite profile divided in four zones, from top to bottom:

1) Canga presented as non-continuous blocks of variable dimensions consisting of Fe-oxyhydroxides and magnetite;

2) Ferrolitic laterite, a dark brown or reddish horizon with earthy consistency and without preservation of original rock fabric;

3) Saprolite, dark brown - greenish in color, slightly more clayey than the laterite and preserving some pyroxene relicts from the original rock;

4) Saprolitized peridotite, corresponding to highly serpentinized harzburgite made up of serpentine and enstatite, with spinel and magnetite as accessory minerals.

The Planeta Rica Peridotites and its lateritic profile are overlaid by the Oligocene-Miocene continental Ciénaga de Oro Formation, suggesting an early Tertiary age for the laterization process (Naciones Unidas, 1975; Dueñas et al., 1981).

\section{Sampling strategy}

Two exposed profiles (CMM-01 and CMM-03) were sampled at the Cerro Matoso mine (Figure 2). The CMM-01 profile has $2 \mathrm{~m}$ of weathered thickness and the CMM-03 profile has $2.8 \mathrm{~m}$ of weathered thickness. A total of eight samples of $\sim 3 \mathrm{~kg}$ each, with their respective duplicates, were collected (Figure 4). The samples from the CMM01 profile are composed by: one sample from the red laterite, one from the green saprolite, and one from the saprolitized peridotite. The samples from the CMM-03 profile comprehend: four samples from the red laterite and one from the saprolitized peridotite.

In the Planeta Rica peridotite, samples were taken from one drill hole (PR-1136), located in the northern part of the Porvenir hill (Figure 3). A total of eight samples with a core diameter of $21 / 2$ inches and weigh between $0.5 \mathrm{~kg}$ and $2.7 \mathrm{~kg}$ (without duplicates) were collected. The total length of the drill hole was $30 \mathrm{~m}$, with approximately $14 \mathrm{~m}$ of weathering profile and saprolitized, intensely serpentinized, and sheared peridotite from this depth onwards. One sample was collected from the canga, three samples from the red laterite, one sample from the transition zone between laterite and saprolite horizons, two samples from the green saprolite, and one sample from the peridotite (Figure 5). The general characteristics of the weathering profiles of both areas are shown in Table 1.

\section{Analytical methods}

Seventeen samples were analyzed for major, minor, and trace elements at Intertek Genalysis Ltd., Perth (Australia) using X-Ray Fluorescence (XRF) spectrometry. Inductively Coupled Plasma - Mass Spectrometry (ICP-MS) was used to determine the PGE and Au contents using Nickel Sulfide Collection Fire Assay, following the method described by Chan and Finch (2001). The detection limit for Pt, $\mathrm{Pd}, \mathrm{Rh}, \mathrm{Ru}$, Ir and Os was $1 \mathrm{ppb}$, and $2 \mathrm{ppb}$ for $\mathrm{Au}$ (Table 2). 
8 / Boletín de la Sociedad Geológica Mexicana / 72 (3) / A201219 / 2020
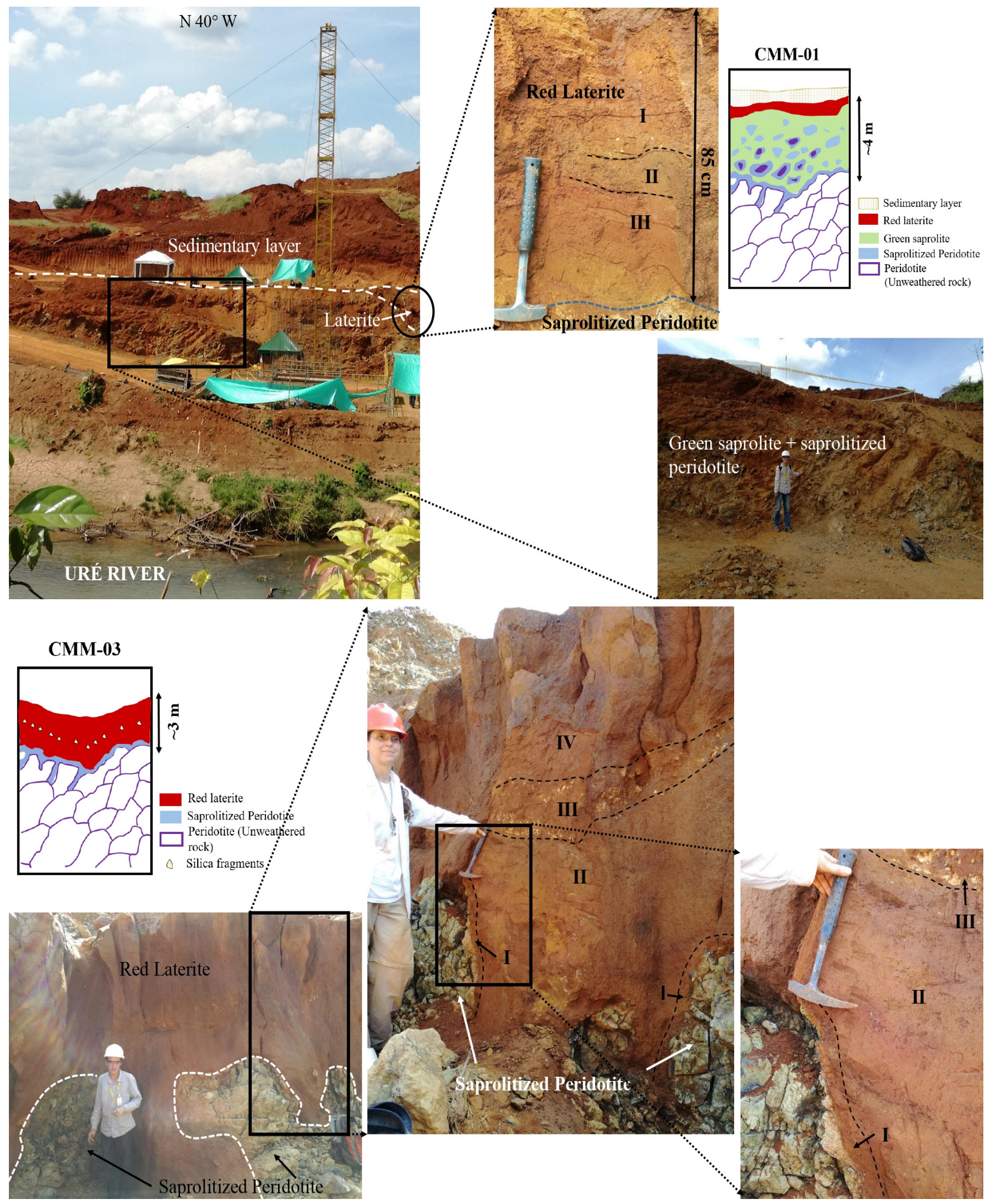

Figure 4 Schematic weathering profiles at sampling stations CMM-01 and CMM-03 in Cerro Matoso. 

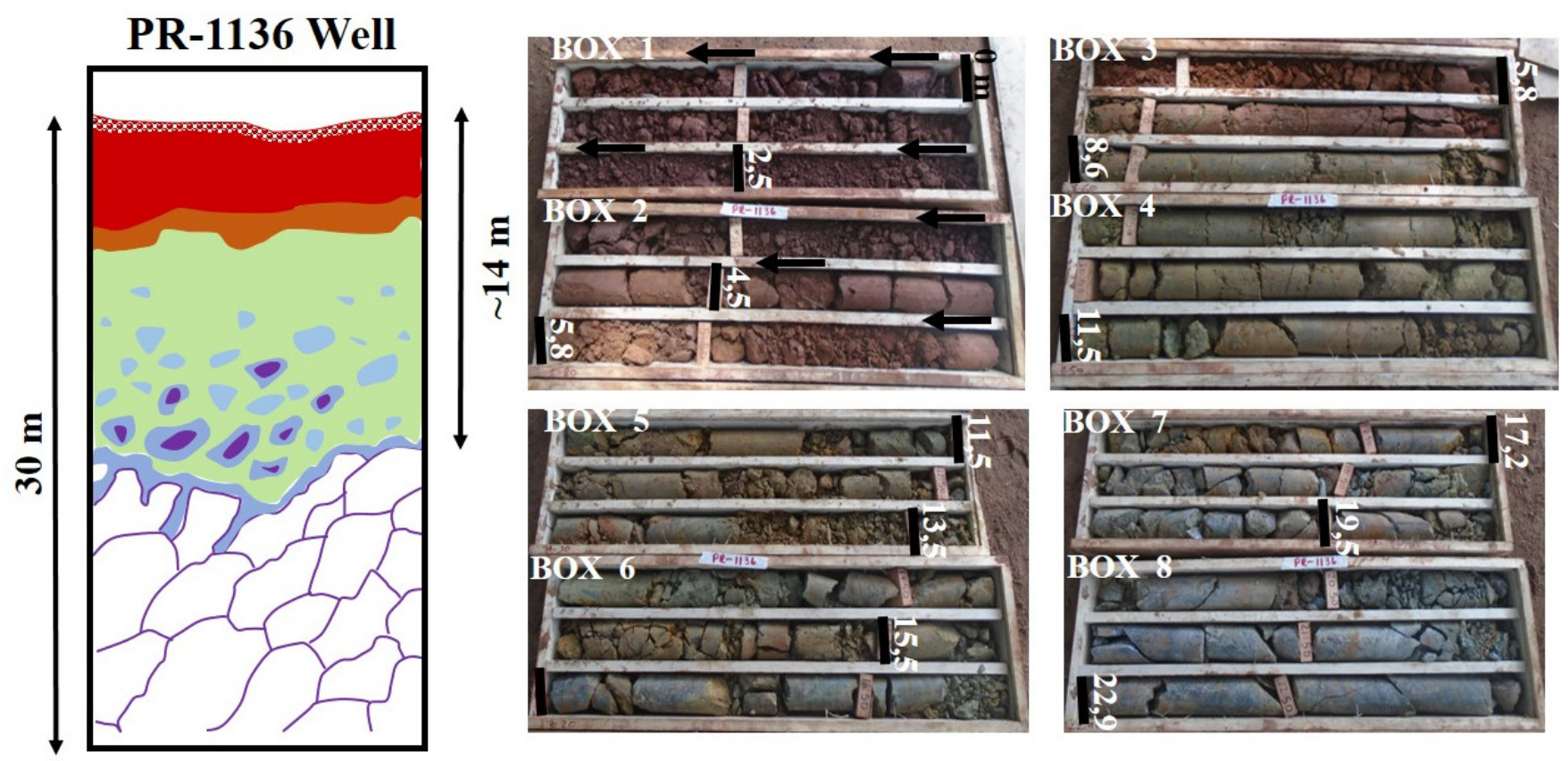

永永 Canga $\square$ Red Laterite

Saprolitized Peridotite

Brown Saprolite $\quad$ Green Saprolite

Peridotite (unweathered rock)

Schematic weathering profile at sampling PR-1136 drill hole and photos of the boxes containing the drill cores in Planeta Rica.

\subsection{GONGENTRATION OF HEAVY MINERALS}

Concentration of PGMs in samples with total PGE content in the order of ppbs and grain sizes $<40 \mu \mathrm{m}$ is extremely difficult by traditional methods such as crushing, screening, magnetic separation, and separation by dense liquids (Aiglsperger et al., 2011, 2015). However, in the last decade hydroseparation has proved to be a very effective technique for non-chemical concentration of heavy minerals. This technique simulates natural beach placer deposits by a combination of laminar water flow at constant pressure with diverse wave impulses. By these means it is possible to process lateritic samples and successfully obtain PGMs from them, even with very small sizes (Aiglsperger et al., 2011, 2015; Navarro-Ciurana et al., 2012). In this study, PGMs were concentrated using hydroseparation techniques in the HS-11 laboratory of the University of Barcelona (http://www. hslab-barcelona.com/) following the methodology described in Aiglsperger et al. (2011).

\subsection{MINERALOGICAL GHARAGTERIZATION}

The resulting heavy mineral concentrates were mounted as polished mono-layer resin blocks and subsequently studied by reflected light microscopy. Afterwards, they were examined by scanning electron microscopy (SEM) using both a Quanta 200 FEI XTE 325/D8395 and a JEOL JSM-7 100 field emission scanning electron microscope (FE-SEM) equipped with an INCA energy-dispersive spectrometer 250 microanalysis system (EDS) at the Centres Científics i Tecnòlogics de la Universitat de Barcelona (CGiTUB). The operating conditions were $20 \mathrm{keV}$ accelerating voltage and $5 \mathrm{nA}$ in backscattered electron (BSE) mode.

\section{Whole rock geochemistry}

\subsection{GERRO MATOSO}

The main component of the limonite horizon (composed of red laterite) in the CMM-01 and 
Table 1. Characteristics of the materials found in the Cerro Matoso and Planeta Rica weathering profiles.

\begin{tabular}{|c|c|}
\hline Clasification & Characteristics \\
\hline $\begin{array}{l}\text { Canga zone } \\
\text { (ferricrete or } \\
\text { duricrust) }\end{array}$ & $\begin{array}{l}\text { Dark reddish brown to very dark brown colour, strongly magnetic, } \\
\text { very hard and very compact. It consists mainly of iron oxides such } \\
\text { as goethite, hematite and magnetite. }\end{array}$ \\
\hline Limonite zone & $\begin{array}{l}\text { Variable colour from red to dark reddish brown, clayey silt texture, } \\
\text { porous, fine to medium subangular blocky structure. Occasionally it } \\
\text { shows rounded holes with iron oxide crusts and black patches of } \\
\text { manganese oxides. It has millimeter and elongated roots. }\end{array}$ \\
\hline Saprolite zone & $\begin{array}{l}\text { Variable color from strong brown to greenish yellow, preserves the } \\
\text { original structure of the rock and has serpentinized peridotite relicts. } \\
\text { The top of the saprolite is usually silty and crumbly and the base is } \\
\text { harder and more compact. It presents bastite after pyroxene and } \\
\text { grains of disseminated millimetric chromite. }\end{array}$ \\
\hline $\begin{array}{l}\text { Unweathered } \\
\text { rock }\end{array}$ & $\begin{array}{l}\text { Light gray to dark color. Very hard rock, compact, massive } \\
\text { structure. Granular texture of mottled appearance, strongly } \\
\text { serpentinized, contains magnetite and bastite after pyroxene. } \\
\text { Sporadic irregular carbonate veins. In general, the rock is notably } \\
\text { sheared and fractured. }\end{array}$ \\
\hline
\end{tabular}

CMM-03 profiles is $\mathrm{Fe}_{2} \mathrm{O}_{3}$ (66-71.6 wt.\%). These values strongly decrease towards the green saprolite and saprolitized peridotite horizons, which show $\sim 13$ wt. $\% \mathrm{Fe}_{2} \mathrm{O}_{3}$. In the saprolite and saprolitized peridotite horizons $\mathrm{SiO}_{2}$ and $\mathrm{MgO}$ are the main components, with values between 41 and 46 wt. $\% \mathrm{SiO}_{2}$ and between 25 to 32 wt. $\% \mathrm{MgO}$, with the highest values corresponding to the saprolitized peridotite. Conversely, the $\mathrm{SiO}_{2}$ and $\mathrm{MgO}$ contents decrease towards the top of the profile (6 wt. $\%$ and 0.6 wt. $\%$, respectively). Thus, these changes in chemistry mark the $\mathrm{Mg}$ discontinuity zone at the boundary between the red laterite and the green saprolite in the CMM-01 profile and at the bottom of the limonite horizon of the CMM03 profile (Figure 6 and Table 2).
Contents in $\mathrm{NiO}$ range between 1.2 and $1.9 \mathrm{wt} . \%$ in the red laterite horizon from both profiles, and they even reach $2.4 \mathrm{wt} . \%$ in the green saprolite horizon from CMM-01 profile. These values decrease down to $<0.06 \mathrm{wt} . \%$ in the saprolitized peridotite. However, the parental rock of the CMM-03 profile is unusually rich in $\mathrm{Ni}$ (up to 2.8 wt. \% $\mathrm{NiO}$ ). $\mathrm{MnO}, \mathrm{Co}_{3} \mathrm{O}_{4}$, and $\mathrm{Cr}_{2} \mathrm{O}_{3}$ have a very similar distribution pattern throughout the weathering profile (Figure 6). Their contents reach a maximum at the top of the profile, with values 0.7 1.44 wt. $\% \mathrm{MnO}, 0.6-1.02$ wt. $\% \mathrm{Co}_{3} \mathrm{O}_{4}$, and up to 3.69 wt. $\% \mathrm{Cr}_{2} \mathrm{O}_{3}$, and they decrease progressively towards the saprolite and saprolitized peridotite to values of $\sim 0.14$ wt. $\%, \sim 0.06-0.19$ wt. $\%$, and $<0.6$ wt. $\%$, respectively. The highest contents of 
A.
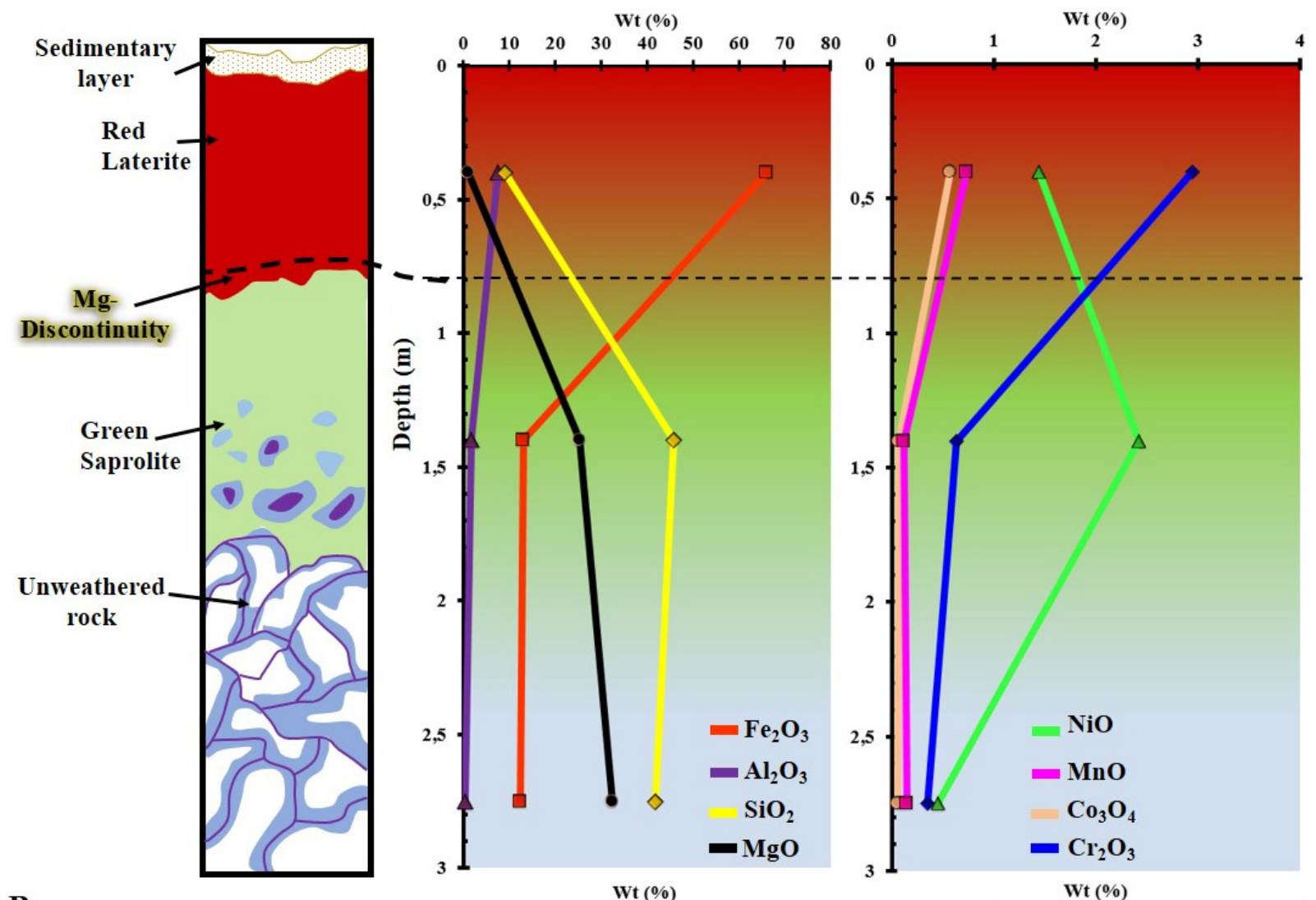

B.

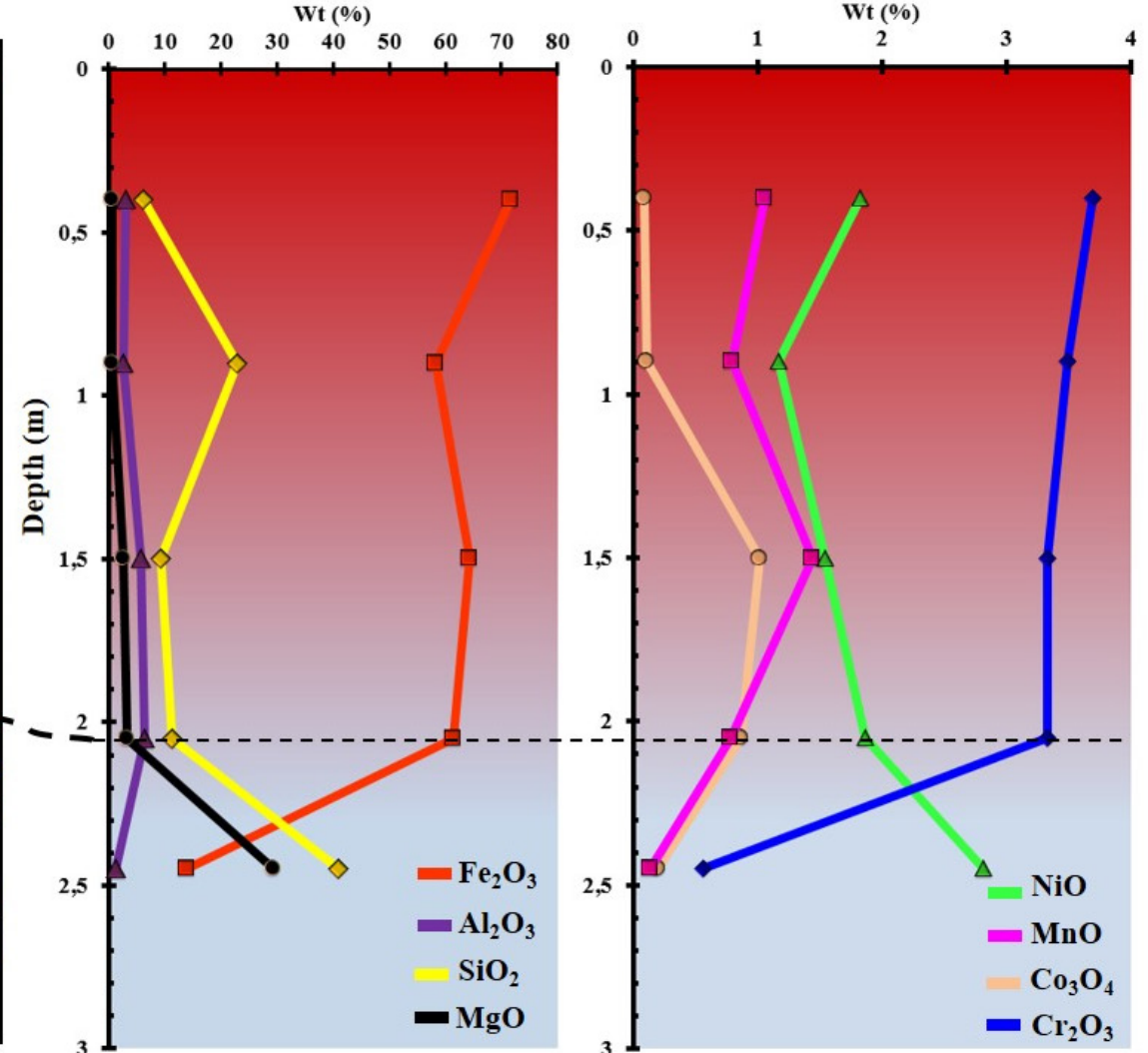

Figure 6 Weathering profiles in Cerro Matoso showing the distribution pattern of relevant major and minor elements. A) CMM-01 profile (Esmeralda hill) and B) CMM-03 profile (pit 2). 
Table 2. Major and minor elements contents (in wt.\%) and PGE and Au concentration (in ppb) of the three studied weathering profiles of Cerro Matoso and Planeta Rica.

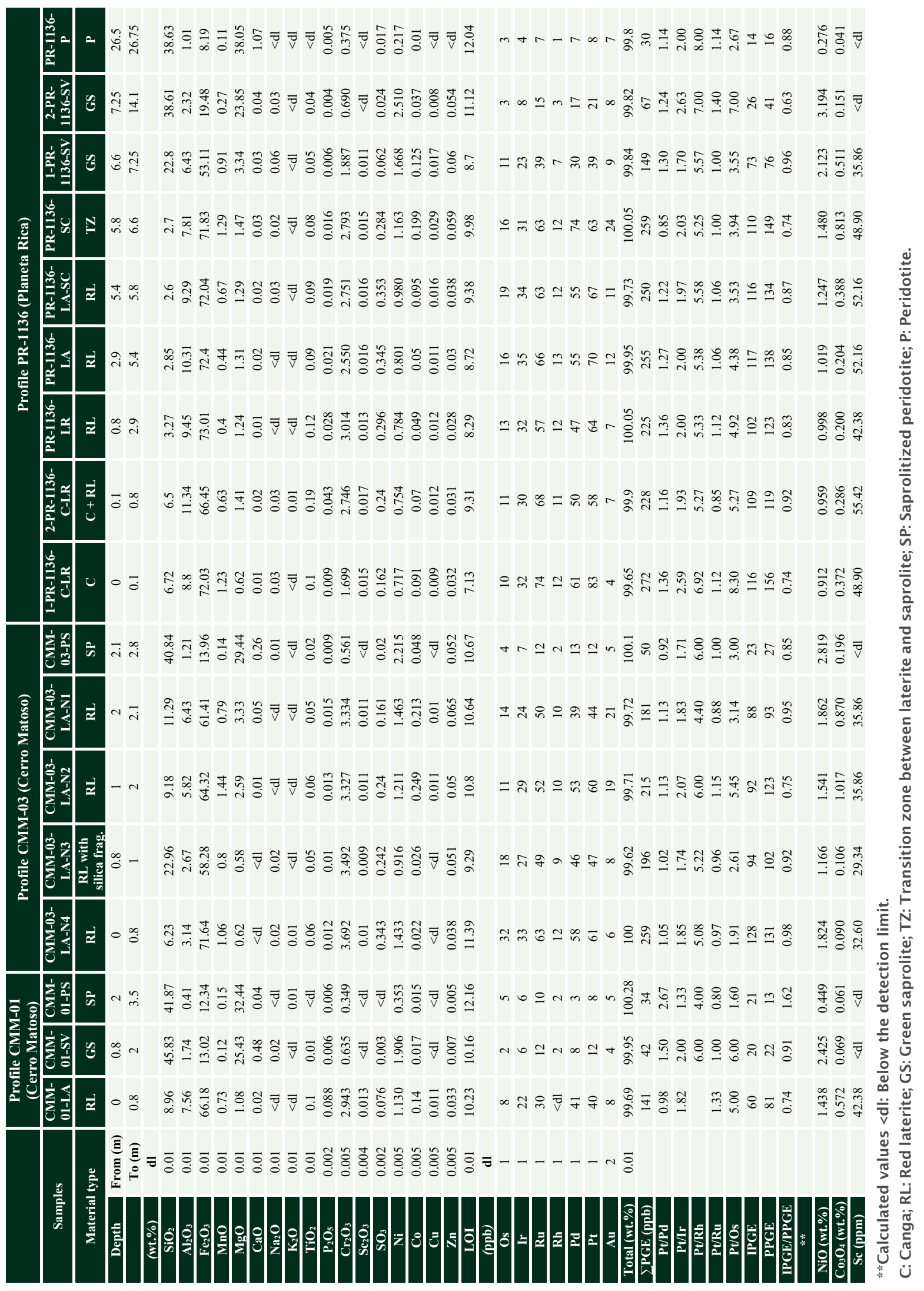


these oxides occur in the limonite horizon of the CMM-03 profile.

\subsection{PLANETA RIGA}

The PR-1136 profile of Planeta Rica (Figure 7 and Table 2) is geochemically similar to the CMM-01 profile from Cerro Matoso. Concentrations of $\mathrm{Fe}_{2} \mathrm{O}_{3}, \mathrm{MnO}, \mathrm{Co}_{3} \mathrm{O}_{4}$, and $\mathrm{Cr}_{2} \mathrm{O}_{3}$ are higher in the limonite horizon composed by canga and red laterite ( 71 wt. $\% \mathrm{Fe}_{2} \mathrm{O}_{3}, \sim 0.6$ wt. $\% \mathrm{MnO}, \sim 0.38$ wt. $\% \mathrm{Co}_{3} \mathrm{O}_{4}$, and up to 3.01 wt. $\% \mathrm{Cr}_{2} \mathrm{O}_{3}$ ), and they strongly decrease towards the bottom of the green saprolite and to the unweathered parent rock $\left(\sim 8\right.$ wt. $\% \mathrm{Fe}_{2} \mathrm{O}_{3}, \sim 0.19$ wt. $\% \mathrm{MnO}, \sim 0.09$ wt. $\% \mathrm{Co}_{3} \mathrm{O}_{4}$, and $<0.9$ wt. $\% \mathrm{Cr}_{2} \mathrm{O}_{3}$ ). However, significant $\mathrm{MnO}$ and $\mathrm{Co}_{3} \mathrm{O}_{4}$ contents are observed in the canga horizon and in the transition between limonite to saprolite zone $(>1.2$ wt. $\% \mathrm{MnO}$ and $>0.8$ wt. $\left.\% \mathrm{Co}_{3} \mathrm{O}_{4}\right) . \mathrm{NiO}$ is concentrated in the saprolitic zone of the profile with values between 2 wt. $\%$ and 3.2 wt. $\%$, but strongly decreases in the unweathered parent rock $(<0.3 \mathrm{wt} . \%)$.

$\mathrm{SiO}_{2}$ and $\mathrm{MgO}$ show the opposite behavior, with highest concentrations in the parent rock ( 38 wt. $\%$, in both oxides) and progressively decreasing towards the top of the profile, reaching values down to 3 wt. $\% \mathrm{SiO}_{2}$ and 0.6 wt. $\% \mathrm{MgO}$.

\section{PGE distribution in weathering profiles}

PGE have been divided in the literature into two groups according to their physical and chemical behaviors (Barnes et al., 1985): the iridium group

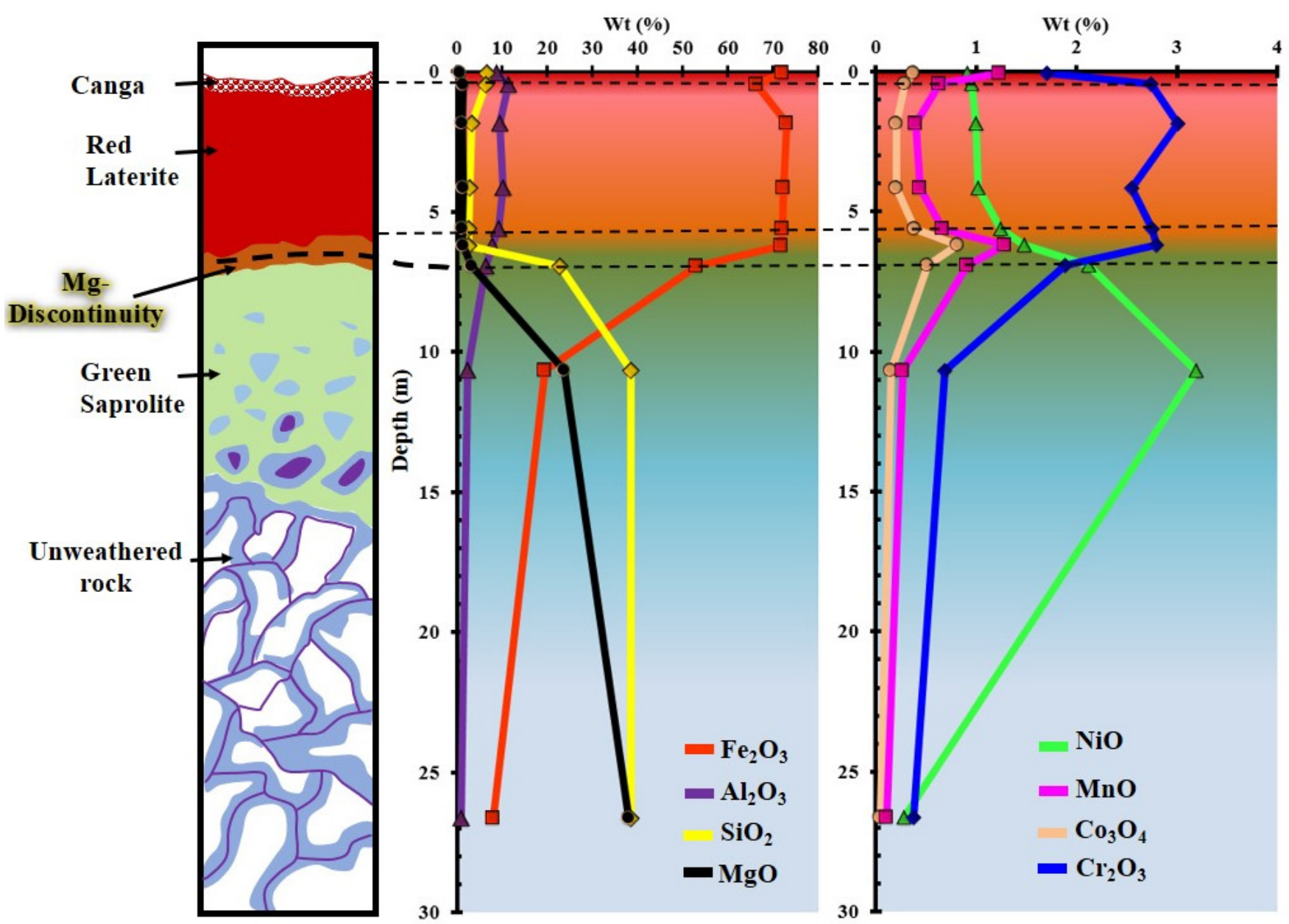

Figure 7 Weathering profile in the hydrous Mg silicate deposit of Planeta Rica (PR-1136) showing the distribution pattern of relevant major and minor elements. 
(IPGE- Os, Ir, Ru) and the palladium group (PPGE$\mathrm{Rh}, \mathrm{Pd}, \mathrm{Pt}$ ), where the latter group includes $\mathrm{Au}$.

\subsection{GERRO MATOSO}

Figure 8 shows the distribution of PGE and $\mathrm{Au}$ in the CMM-01 and CMM-03 weathering profiles. In both profiles the highest PGE contents occur at the limonite horizon and show a strong decrease in the saprolitic horizon and the saprolitized peridotite. In all cases, $\mathrm{Pt}$ and $\mathrm{Pd}$ are more abundant than Os, Ir, and Rh.

The PGE concentration in the red laterite horizon of the CMM-01profile is $141 \mathrm{ppb}$. In contrast, the same horizon in the CMM-03 profile contains between $181 \mathrm{ppb}$ and $259 \mathrm{ppb}$ PGE, the latter corresponding to the uppermost interval of red laterite. In both weathering profiles the total PGE contents in the saprolite and unweathered rock are $<50 \mathrm{ppb}$ (Table 2).

The concentration of $\mathrm{Pt}, \mathrm{Pd}$ and $\mathrm{Ru}$ in the red laterite horizon in CMM-01 profile reaches up to 41, 40 and $30 \mathrm{ppb}$, respectively. Among the other PGE, Ir concentrates only up to $22 \mathrm{ppb}$ in the limonite horizon, Os up to $8 \mathrm{ppb}$, and the $\mathrm{Rh}$ content is below the detection limit (Table 2). The concentrations of all these elements in both the green saprolite and the saprolitized peridotite are between $2 \mathrm{ppb}$ and $12 \mathrm{ppb}$. Au contents range between $4 \mathrm{ppb}$ and $8 \mathrm{ppb}$ in the whole profile.

In the CMM-03 profile the highest PGE contents correspond to $\mathrm{Ru}, \mathrm{Pt}$, and $\mathrm{Pd}$, with values ranging from 49 to $63 \mathrm{ppb} \mathrm{Ru}, 44$ to $61 \mathrm{ppb} \mathrm{Pt}$, and 39 to $58 \mathrm{ppb} \mathrm{Pd}$, whereas the lower ones correspond to Rh (9-12 ppb), Os (11-32 ppb), and $\operatorname{Ir}(24-33 \mathrm{ppb})$. The highest PGE values are observed in the first and third intervals of the red laterite, in which the horizon contains $63 \mathrm{ppb} \mathrm{Ru}$, $61 \mathrm{ppb} \mathrm{Pt}$, and $58 \mathrm{ppb} \mathrm{Pd}$. All PGE are depleted in the saprolitized peridotite, with concentrations between $4 \mathrm{ppb}$ and $13 \mathrm{ppb}$. Au contents are very low ( $\sim 6 \mathrm{ppb}$ on average) with a major value of 21 $\mathrm{ppb}$ in the transition zone between the red laterite and saprolitized peridotite (Table 2).

\subsection{PLANETA RICA}

Figure 9 shows the distribution of PGE and $\mathrm{Au}$ in the PR-1136 profile, where PGE tend to concentrate towards the limonite horizon, but mainly in canga (272 ppb) and the transition zone (259 ppb). Conversely, PGE are strongly depleted in the green saprolite and in the unweathered peridotite (total PGE range between $30 \mathrm{ppb}$ and $149 \mathrm{ppb}$ ). $\mathrm{Pt}, \mathrm{Ru}$, and $\mathrm{Pd}$ are generally more abundant than $\mathrm{Ir}, \mathrm{Rh}$, and $\mathrm{Os}$.

In the limonite and transition zone the Pt content ranges between 58 and $83 \mathrm{ppb}, \mathrm{Ru}$ between 57 and $74 \mathrm{ppb}$, and Pd between 47 and 74 ppb. Ir (30-35 ppb), Rh (11-13 ppb), and Os (10-19 ppb) are less abundant. In the saprolite horizon, PGE varies between $3 \mathrm{ppb}$ and $39 \mathrm{ppb}$ and decrease to values of $1 \mathrm{ppb}$ and $8 \mathrm{ppb}$. Au contents are generally very low $(\sim 8 \mathrm{ppb})$, although they reach $24 \mathrm{ppb}$ in the transition zone of the laterite profile (Table 2).

\subsection{IPGE VS PPGE IN GERRO MATOSO AND PLANETA RICA}

The IPGE/PPGE ratios for the three analyzed profiles are $<1 \quad(\sim 0.88)$, which indicates that PPGE>IPGE. An exception is observed in the saprolitized peridotite zone of the CMM-01 profile, where the IPGE/PPGE ratio reaches 1.6 (Table 2). However, the general behavior of both groups of elements is very similar throughout the weathering profile (Figure 10). Interestingly, the PPGE content in the limonite horizon of Planeta Rica is above $119 \mathrm{ppb}$, whereas in Cerro Matoso PPGE content in this horizon ranges between 81 and $131 \mathrm{ppb}$.

\section{PGM Mineralogy}

Sample PR-1136-SC, corresponding to the transition zone between the limonite and saprolite horizons form Planeta Rica, was selected for 
A.

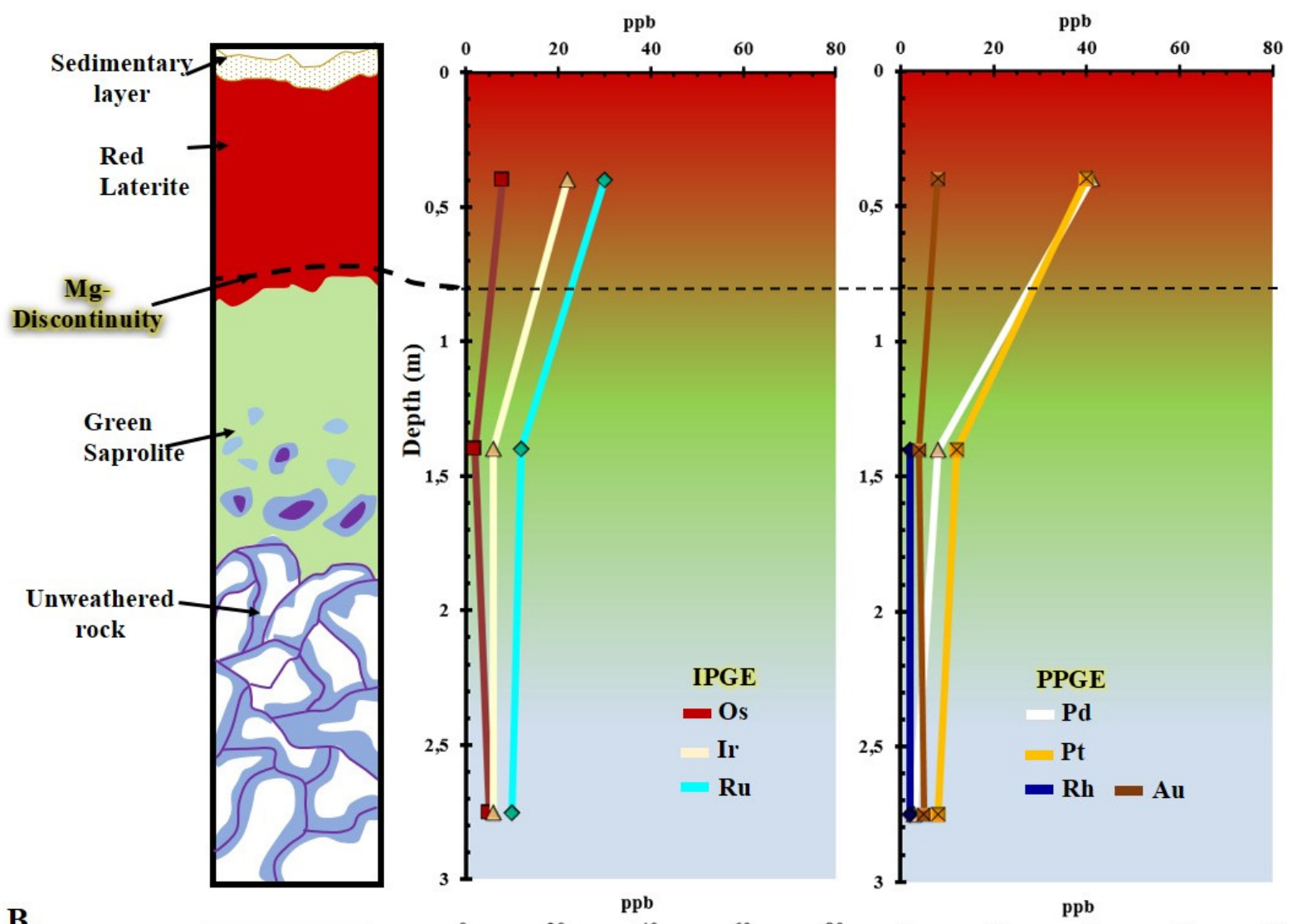

B.

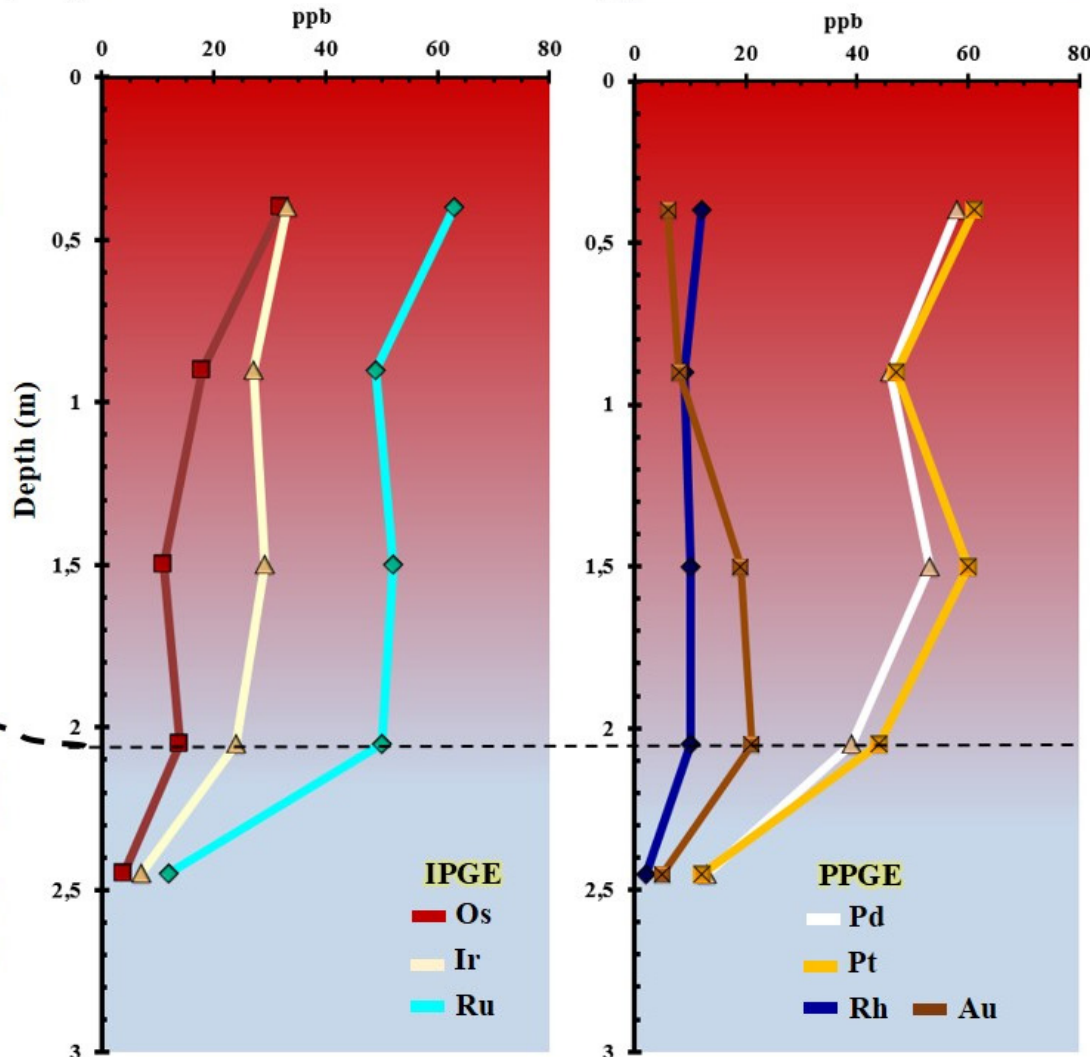

Figure 8 Weathering profiles in Cerro Matoso showing the distribution of PGE and Au. A) CMM-01 profile (Esmeralda Hill) and B) CMM03 profile (Pit 2). 
PGM concentration by hydroseparation do to its higher PGE contents (259 ppb). The sample also contains high $\mathrm{MnO}(1.29$ wt. $\%)$ and $\mathrm{Co}_{3} \mathrm{O}_{4}(0.2$ wt.\%), which are good indicators of PGE concentration (Ndjigui and Bilong, 2010; Aiglsperger et al., 2016a, 2016b).

Two types of PGM grains were found: i) Pt-IrFe-Ni alloys included in Fe-oxyhydroxide (Figure 11) showing elongated anhedral morphology, irregular edges, and a rough surface; and ii) tiny, anhedral grains, with grain size ranging from 0.1 $\mu \mathrm{m}$ to $1 \mu \mathrm{m}$, adhered to interstices of inter-aggregated and highly porous pyrite crystals with framboidal texture (Figure 12). These grains are probably PGM; however, due to their small size it was not possible to obtain an accurate X-ray spectrum using SEM-EDS.
The shape and occurrence of these grains suggest secondary formation, since the typical shape of primary crystals of igneous origin is euhedral with polygonal sections lacking evidences of abrasion (Bowles, 1986; Ndjigui and Bilong, 2010; González-Jiménez et al., 2014; Aiglsperger et al., 2015; Farré-de-Pablo et al., 2017).

\section{Discussion}

\subsection{ELEMENTS MOBILITY IN THE GERRO MATOSO AND PLANETA RICA PROFILES}

The geochemical distribution of $\mathrm{Fe}_{2} \mathrm{O}_{3}, \mathrm{MnO}$, $\mathrm{Co}_{3} \mathrm{O}_{4}$, and $\mathrm{Cr}_{2} \mathrm{O}_{3}$ in the $\mathrm{CMM}-01$ profile of Cerro Matoso and the PR-1136 profile of Planeta

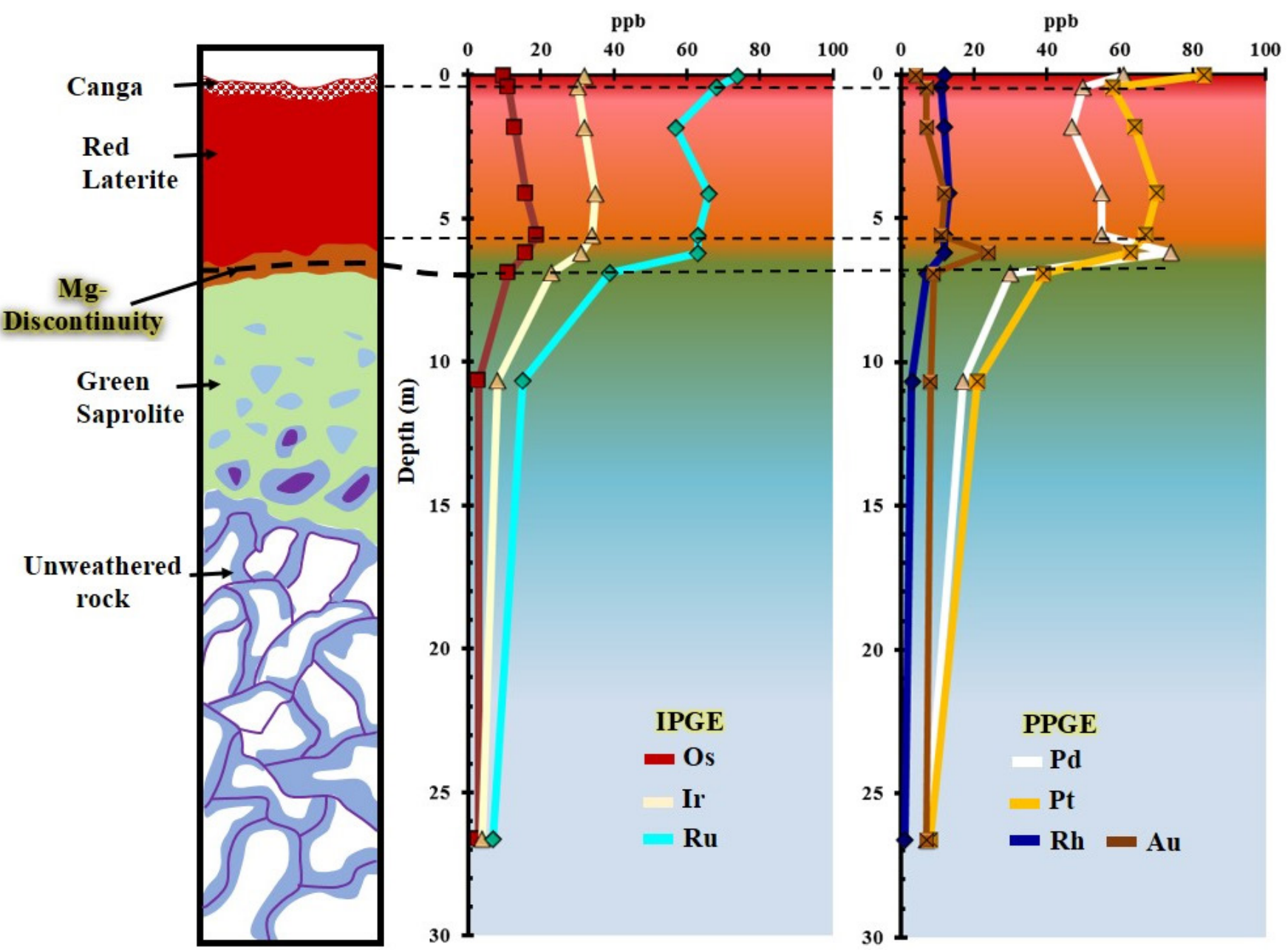

Figure 9 Weathering profile of the PR-1136 drill hole (Planeta Rica) showing the distribution of PGE and Au. 
Rica (Figures 6A, 7 and Table 2) show that the highest concentration of these elements are in the limonite horizon. However, their concentrations strongly decrease in the $\mathrm{Mg}$ discontinuity zone (transition zone between red laterite and green saprolite) and towards the unweathered parent rock. Conversely, $\mathrm{SiO}_{2}$ and $\mathrm{MgO}$ show inverse trends along the profile, sharply increasing their concentrations from the $\mathrm{Mg}$ discontinuity zone towards the parent rock. $\mathrm{NiO}$ concentrates in the saprolitic horizon (up to 3.19 wt.\%) in profiles from both areas. However, $\mathrm{NiO}$ content in the saprolitized peridotite of the CMM-03 profile reaches values of 2.8 wt. $\%$. This $\mathrm{NiO}$ enrichment is probably due to garnierite filling microfractures in the rock, as reported in several studies which show the preferential concentration of Ni minerals in veins and fractures and as thin coatings in joints (Freyssinet et al., 2005; Cluzel and Vigier, 2008; Villanova-de-Benavent et al., 2014). This chemical behavior of major oxides in the Ni-laterite profiles from Cerro Matoso and Planeta Rica is characteristic of the hydrous $\mathrm{Mg}$ silicate-type deposits (Cornwall, 1966; Brand et al., 1998; Freyssinet et al., 2005; Villanova-de-Benavent et al., 2014; Aiglsperger et al., 2016a).

Furthermore, the CMM-03 profile of Cerro Matoso, located in Pit 2 (Figure 2), shows a red laterite very rich in iron $\left(\mathrm{Fe}_{2} \mathrm{O}_{3}>60\right.$ wt.\%), with $\mathrm{NiO}$ contents up to 1.8 wt. $\%$ and $\mathrm{Cr}_{2} \mathrm{O}_{3}$ contents up to 3.7 wt. $\%$, which are almost $1 \%$ higher than their contents in the limonite horizon of CMM-01 and PR-1136 (Figure 6B and Table 2). According to the mineralogical study as well
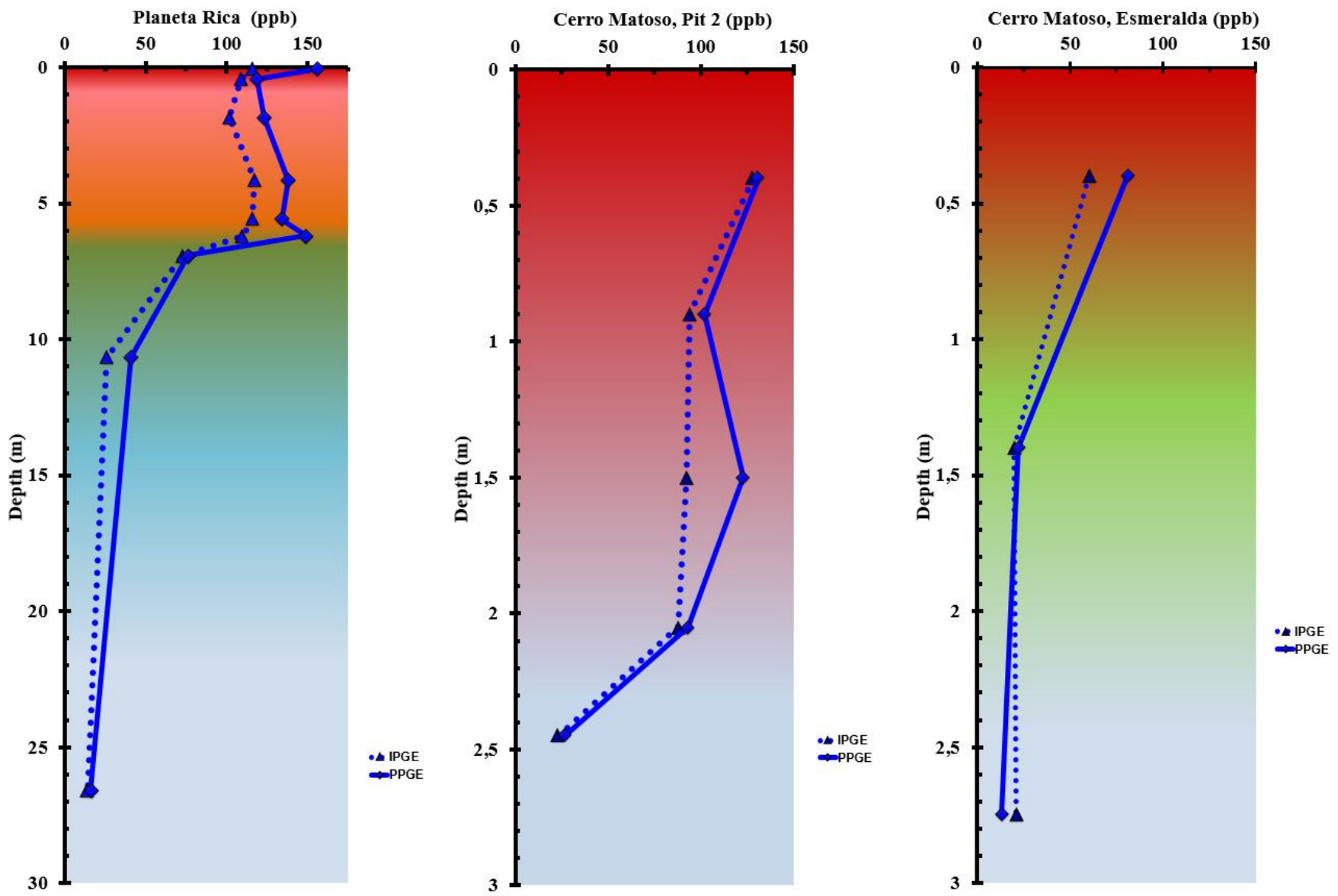

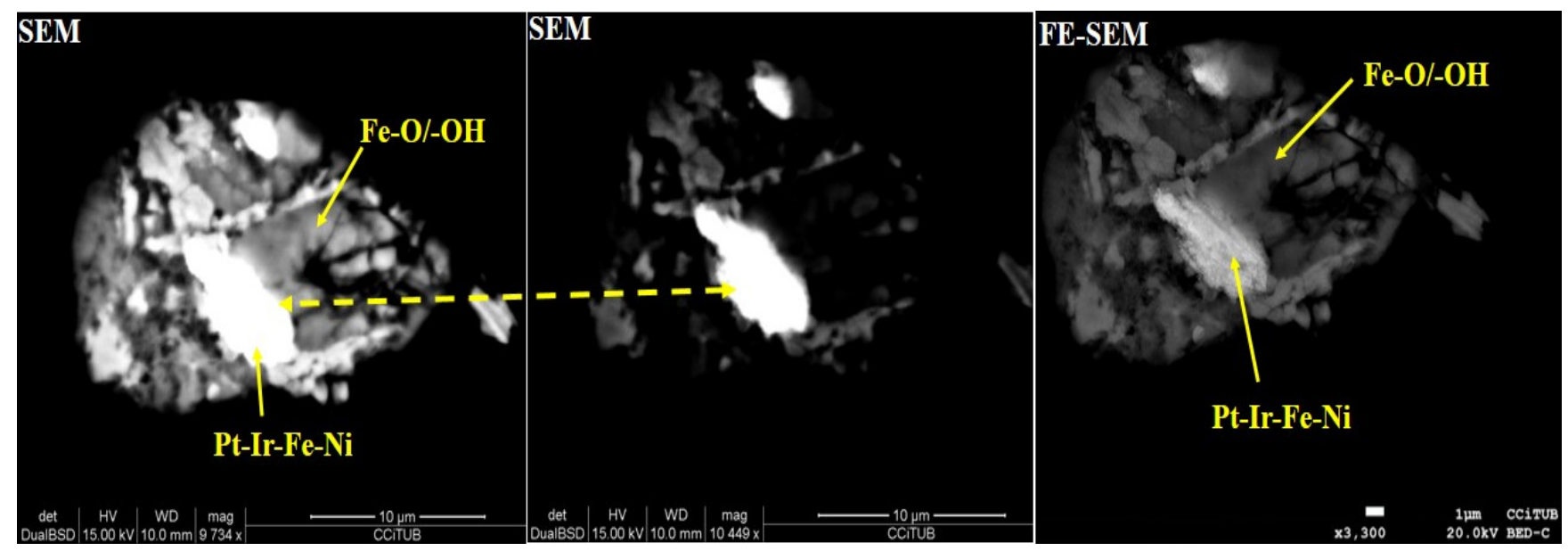

Figure 11 Backscattered electron (BSE) images of PGM (Pt-Ir-Fe-Ni) grains included within a Fe-oxyhydroxide (Fe-O/-OH).

as the thermodifferential and thermogravimetric analyses carried out by SUMICOL S.A. (2002), the lateritic material from Pit 2 has more than $65 \%$ Fe-oxyhydroxides, mainly goethite. Based on the above results, the GMM-03 profile from Cerro Matoso could represent an oxide-type deposit. Oxide-type deposits can be present in all climatic environments and are characterized by a Fe-, Cr-, and $\mathrm{Al}$-rich and $\mathrm{SiO}_{2}$ and $\mathrm{MgO}$ poor horizon, dominated by Fe-oxyhydroxides (e.g., goethite) where the Ni is mainly hosted, that forms between the upper saprolite and the lower limonite horizon (Brand et al., 1998; Gleeson et al., 2003; Freyssinet et al., 2005; Proenza, 2015). Brand et al. (1998) noted that most Ni-laterite deposits contain hydrous $\mathrm{Mg}$ silicate-type and oxide-type profiles, and Tauler $e t$ al. (2017) reported an example of "hybrid hydrous $\mathrm{Mg}$ silicate-clay silicate" in Ni-laterite deposit from Loma Ortega (Falcondo mine, Dominican Republic). Therefore, in agreement with Castro (1987) and Gleeson et al. (2004), we consider that Cerro Matoso deposit is dominantly a hydrous $\mathrm{Mg}$ silicate-type, but locally also exhibits the characteristics of an oxide-type deposit. Mineralogical and further geochemical studies are needed to confirm this conclusion.

\subsection{ENRICHMENT OF PGE IN GERRO MATOSO AND PLANETA RIGA LATERITES}

In Planeta Rica, the highest PGE contents from the three analyzed laterite profiles occur towards the limonite zone and transition zone, and show a strong decrease towards the saprolite and underlying serpentinized peridotite (parent rock).

The preferential concentration of PGE towards the upper levels of the weathering profile, with respect to the initial concentrations in the rock, as well as the positive correlations between them, indicate that PGE mobilize in different proportions throughout the weathering profile. $\mathrm{Pt}$, $\mathrm{Ru}$, and $\mathrm{Pd}$ are more mobile than Ir, Os, and Rh. Similar results were previously observed by Fuchs and Rose (1974), Plimer and Williams (1987), Salpéteur et al. (1995), Ndjigui and Bilong (2010), and Aiglsperger et al. (2015).

Some studies show that the mobility of the PGE can be related to laterization processes that favor the migration of these metals towards the limonite zone (Plimer and Williams, 1987; Eliopoulos and Economou-Eliopoulos, 2000; Talovina and Lazarenkov, 2001; Ndjigui and Bilong, 2010; Aiglsperger et al., 2015). This mobilization and redistribution may be affected by the Eh-pH ratio, the $\mathrm{Cl}$ concentration from water in the soil, and the mode of occurrence of PGE in the parent rock prior to weathering (Fuchs and Rose, 1974; Bowles et al., 1994a, 1994b; Salpéteur et al., 1995).

Authors such as Colombo et al. (2008) showed that $\mathrm{Pt}$ and $\mathrm{Pd}$ are redox sensitive elements and can be mobilized as inorganic complexes at low temperature. Furthermore, Cl-rich solutions at low temperature favor the mobility of $\mathrm{Pt}$ and $\mathrm{Pd}$, although high Pt mobility also requires acidic con- 


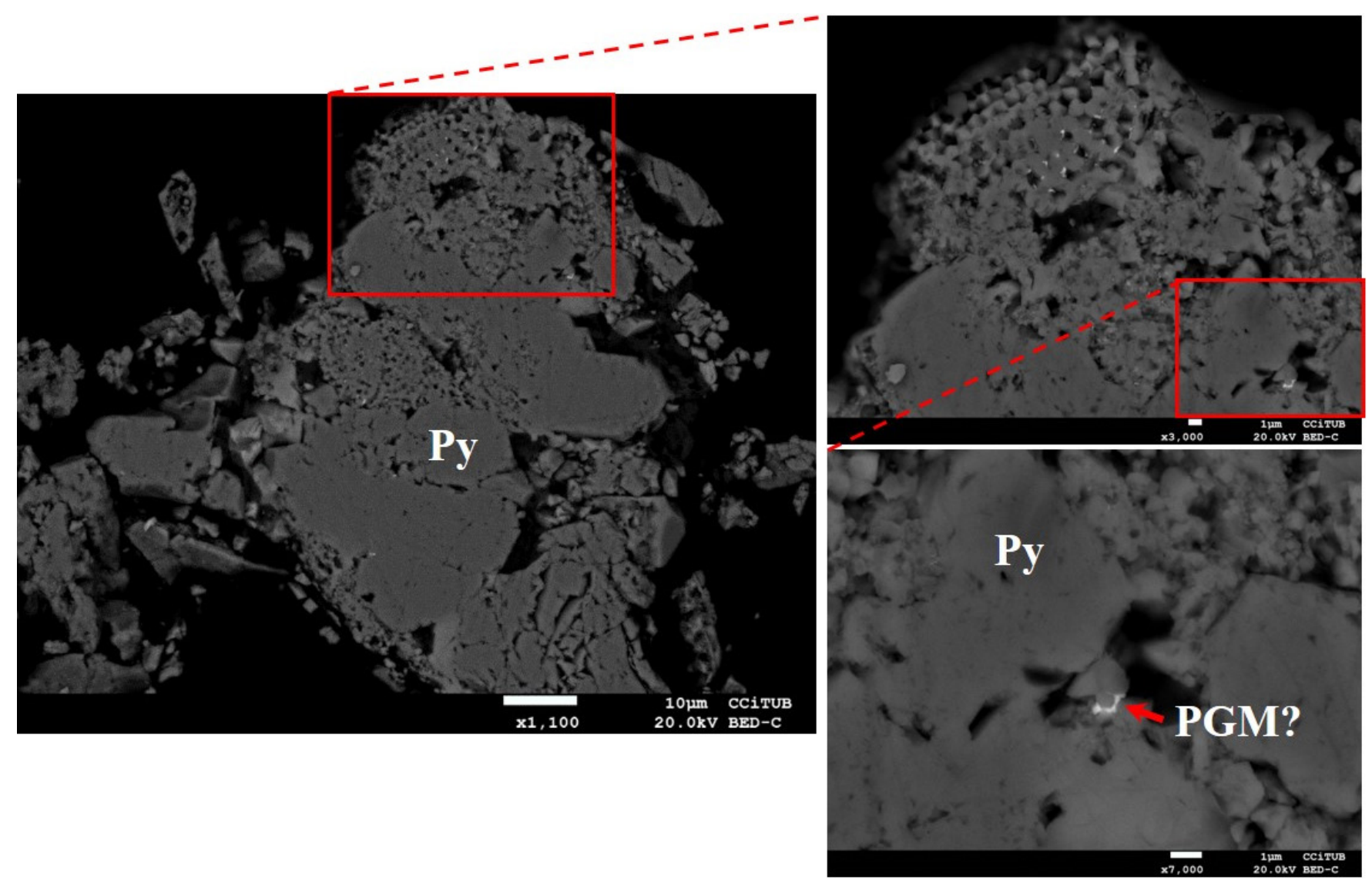

Figure 12 BSE image of porous pyrite grains (Py) hosting submicrometric crystals, possibly PGM.

ditions $(\mathrm{pH}<6)$ (Fuchs and Rose, 1974; Plimer and Williams, 1987; Salpéteur et al., 1995; Gammons, 1996). These conditions can lead to dissolution of PGE-bearing minerals, subsequent differentiation, migration, and accumulation in oxidized profiles (Plimer and Williams, 1987; Bowles et al., 1994a, 1994b); or co-precipitation of alloys rich in these metals coexisting with iron and manganese oxides (Bowles et al., 1994a, 1994b; Salpéteur et al., 1995; Ndjigui and Bilong, 2010).

Although total PGE concentration in the limonitic zone in Cerro Matoso and Planeta Rica is less than $300 \mathrm{ppb}$, this value is comparable to the total PGE contents reported by Aiglsperger et al. $(2015,2016 \mathrm{a}, 2016 \mathrm{~b})$ in the equivalent weathering horizons from Ni-laterite deposit of Falcondo, in Dominican Republic. These horizons in the Ni-laterite deposit of Falcondo display PGE values between 250 and $640 \mathrm{ppb}$. However, the final product obtained by Falcondo after processing the mined material (i.e. ferronickel-cone after pyrometallurgical extraction) shows an increase up to 2 ppm of the total PGE contents. Therefore, these authors considered the Ni-laterite deposit as a potential nonconventional PGE source. Similarly, Lazarenkov et al. (2005) demonstrated that PGMs are lost in tailings, sulfide concentrates, and in endnickel products (with PGE contents of 2-6 ppm in sulfide concentrates) of the Nikaro and Moa ore dressing plants (main nickel deposits of Cuba).

\subsection{PGM IN THE LATERITE PROFILE OF PLANETA RICA}

The highest concentrations of PGE in the Planeta Rica weathering profile are found in the limonite horizon, which is characterized by a Fe-oxyhydroxides domain. In this profile, a complex Pt-Ir-Fe-Ni alloy was found as an inclusion within a Fe-oxyhydroxide in the transition zone between the limo- 
nite and saprolite horizons. This is in accordance with observations made by Oberthür and Melcher (2005) and Ndjigui and Bilong (2010), which indicated that high concentrations of $\mathrm{Pt}, \mathrm{Pd}$, and $\mathrm{Ru}$, as well as transition metals such as $\mathrm{Ni}, \mathrm{Co}, \mathrm{Cu}$, and $\mathrm{Zn}$, could be hosted by secondary minerals like Fe-oxyhydroxides or smectites. The PGM found in the present study is similar to the densely packed Pt-Ir-Fe-Ni nanoparticles within pores of Fe oxides identified in Loma Peguera deposit, in Dominican Republic (Aiglsperger et al., 2015, 2016b). Like in the Dominican Republic case, the PGE alloys could correspond to primary PGM formed during the magmatic stage and subsequently dissolved during the serpentinization and/or laterization processes. The PGE alloys would form in situ as neoformed secondary PGM (Aiglsperger et al., 2016b).

PGE are highly siderophile elements (O'Driscoll and González-Jiménez, 2016, and references therein) and, according to some experimental studies, Pt and Pd mobilize during pyrite oxidation (Plimer and Williams, 1987). Considering this, we infer that the $<1 \mu \mathrm{m}$ bright particles within the interstices of altered pyrite aggregates correspond to PGE-bearing particles that would constitute evidence of PGM neoformation taking place adhered to the porous edges of the pyrite. Furthermore, thermodynamic calculations on PGE solubility in water at different $\mathrm{Cl}$ contents in lateritic soils showed that $\mathrm{Pt}$ and $\mathrm{Pd}$ solubility and mobility in natural waters of weathering crusts are strongly influenced by the $\mathrm{Cl}$ concentration (Talovina and Lazarenkov, 2001). In addition, those elements are transported in solution under acidic $(\mathrm{pH}<6)$ and high Eh $(>0.4)$ conditions in Fe-rich soils, which could explain the transport of $\mathrm{Pt}$ to the interstices of the porous pyrite.

\section{Conclusions}

The geochemical patterns of the CMM-01 profile from Cerro Matoso and PR-1136 profile from Planeta Rica show high $\mathrm{Fe}_{2} \mathrm{O}_{3}$ and $\mathrm{Al}_{2} \mathrm{O}_{3}$ contents and low $\mathrm{SiO}_{2}$ and $\mathrm{MgO}$ contents in their limonite horizons, which is characteristic of hydrous $\mathrm{Mg}$ silicate-type deposits. However, Cerro Matoso deposit also contains some areas with characteristics from oxide-type deposits, as indicated by the CMM-03 profile.

The highest PGE values in Cerro Matoso and Planeta Rica are concentrated in the limonite zone, and their concentration decreases from the upper level of the green saprolite to the unweathered peridotite. The distribution and the positive correlation between them indicate that PGE mobilize in different proportions, being $\mathrm{Pt}, \mathrm{Pd}$, and $\mathrm{Ru}$ more mobile than Os, Ir, and Rh.

The high affinity between PGE and Fe favors the formation of secondary PGE-Fe mineral alloys, such as the Pt-Ir-Fe-Ni PGM hosted in a Fe-oxyhydroxide. Similarly, it is inferred that neoformation of irregular nanoparticle sized PGM occurred encrusted in the interstices of altered pyrite aggregates. In these cases, Pt may have been transported in solution under acidic and high-Eh conditions.

PGE concentration in Cerro Matoso and Planeta Rica limonite horizons are of the order of ppb. However, applying adequate refinery methods could increase the PGE concentration in the final products and they could be recovered as by-products. Therefore, these two deposits can be considered as unconventional PGE deposits. This consideration could create a positive cash flow for the refinery operation and increase the viability of future projects.

\section{Acknowledgements}

This research has been financially supported by the Asociación Colombiana de Geólogos y Geofísicos del Petróleo (ACGGP) through the XV Convocatoria ACGGP-Aportes Fondo Corrigan y Promoción de Jóvenes Investigadores ARES, the 4002 project of the Fundación para la Promoción de la Investigación y la Tecnología del Banco de la República, the 35671 project of the Universidad Nacional de Colombia, as well as by a master 
degree grant sponsored by Fundación Juan Pablo Gutiérrez Cáceres through a cooperation agreement with the Universidad Nacional de Colombia. We also want to thank the staff of Cerro Matoso mine (operated by South32 Ltd), specially to the engineers: Wilson Escobar, Esteban Gómez, Gonzalo Castillo, Cristian Conde, Yuli, Yuris Daza, and Guillermo Urango for allowing the sampling at the different mine sites and access to the drill holes on the Porvenir hill during the exploration campaign in 2016-2017. Finally, we want to thank the students of the SEMERU research group, who supported the fieldwork and some phases of sample processing, especially Esteban Arrieta and Alejandro Argumedo, and we want to thank the anonymous reviewers for their criticism that greatly improved our manuscript.

\section{References}

Agencia Nacional de Minería (ANM), 2015, Platino (en línea): Bogotá, Colombia, Agencia Nacional de Minería, available in <anm.gov. co/sites/default/files/DocumentosAnm/ platino.pdf.>, visited on October 30th, 2016.

Aiglsperger, T., Proenza, J.A., Zaccarini, F., Labrador, M., Navarro-Ciurana, D., 2011, Looking for needles in a haystack: how to find PGM in laterites by using hydroseparation techniques: Revista de La Sociedad Española de Mineralogía, 15, 23-24.

Aiglsperger, T., Proenza, J.A., Zaccarini, F., Lewis, J.F., Garuti, G., Labrador, M., Longo, F., 2015, Platinum group minerals (PGM) in the Falcondo Ni-laterite deposit, Loma Caribe peridotite (Dominican Republic): Mineralium Deposita, 50, 105-123. https:// doi.org/10.1007/s00126-014-0520-9

Aiglsperger, T., Proenza, J.A., Lewis, J. F., Labrador, M., Svojtka, M., Rojas-Purón, A., Durisova, J., 2016a, Critical metals (REE, Sc, PGE) in Ni Laterites from Cuba and the Dominican Republic: Ore Geology Reviews, 73, 127-147. https://doi.org/10.1016/j. oregeorev.2015.10.010
Aiglsperger, T., Proenza, J.A., Font-Bardia, M., Baurier-Aymat, S., Galí, S., Lewis, J. F., Longo, F., 2016b, Supergene neoformation of Pt-Ir-Fe-Ni alloys: multistage grains explain nugget formation in Ni Laterites: Mineralium Deposita, 52, 1069-1083. https://doi. org/10.1007/s00126-016-0692-6

Augé, T., Legendre, O., 1994, Platinum-group element oxides from the Pirogues ophiolitic mineralization, New Caledonia: origin and significance: Economic Geology, 89, 1454-1468. http://dx.doi.org/10.2113/ gsecongeo.89.7.1454

Barnes, S., Naldrett, A., Gorton, M., 1985, The origin of the fractionation of platinumgroup elements in terrestrial magmas: Chemical Geology, 53, 303-323. https:// doi.org/10.1016/0009-2541(85)90076-2

Bartok, P., Renz, O., Westermann, G., 1985, The Siquisique ophiolites, Northern Lara State, Venezuela: A discussion on their Middle Jurassic ammonites and tectonic implications: Geological Society of America Bulletin, 96, 1050-1055. https://doi.org/10.1130/00167606(1985)96<1050: TSONLS > 2.0. $\mathrm{CO} ; 2$

Bayona, G., Cardona, A., Jaramillo, C., Mora, A., Montes, C., Valencia, V., Ayala, C., Montenegro, O., Ibañez-Mejia, M., 2012, Early Paleogene magmatism in the northern Andes: Insights on the effects of Oceanic Plateau-continent convergence: Earth and Planetary Science Letters, 331-332, 97-111. https://doi.org/10.1016/j.epsl.2012.03.015

Bowles, J.F.W., 1986, The Development of Platinum-Group Minerals in laterites: Economic Geology, 81, 1278-1285. https:// doi.org/10.2113/gsecongeo.81.5.1278

Bowles, J.F.W., Gize, A.P., Cowden, A., 1994a, The mobility of the platinum-group elements in the soils of the Freetown Peninsula, Sierra Leone: Canadian Mineralogist, 32, 957-967.

Bowles, J.F.W., Gize, A.P., Vaughan, D.J., Norris, S.J., 1994b, Development of platinum group minerals in laterites-initial comparison of organic and inorganic controls. Transactions 
of the Institution of Mining and Metallurgy, Technical Note, 103, B53-B55. http:// pascal-francis.inist.fr/vibad/index. php?action $=$ getRecordDetail\&idt $=6384952$

Brand, N.W., Butt, G.R.M., Elias, M., 1998, Nickel Laterites: Classification and features: Journal of Australian Geology and Geophysics, 17, 81-88. https://d28rz98at9flks.cloudfront. net/81525/Jou1998_v17_n4_p081.pdf

Castro, H., 1987, Minerales de Níquel, en Ingeominas (ed.), Recursos Minerales de Colombia: Bogotá, 1, 327-368.

Cediel, F., Shaw, R.P., Cáceres, C., 2003, Tectonic assembly of the northern Andean block, in Bartolini, G., Buffler, R., Blickwede, J., (eds.), The Circum-Gulf of Mexico and the Caribbean: Hydrocarbon habitats, basin formation, and plate tectonics, AAPG Memoir 79, 79, 815-848. https://doi. org/10.1306/M79877

Chan, T.K., Finch, I.J., 2001, Determination of platinum-group elements and gold by inductively coupled plasma mass spectrometry, in Australian Platinum Conference: Perth, Western Australia, 1-9.

Cluzel, D., Vigier, B., 2008, Syntectonic mobility of supergene nickel ores of New Caledonia (Southwest Pacific). Evidence from garnierite veins and faulted regolith: Resource Geology, 58, 161-170. https://doi. org/10.1111/j.1751-3928.2008.00053.x

Colombo, C., Oates, C.J., Monhemius, A.J., Plant, J.A., 2008, Complexation of platinum, palladium and rhodium with inorganic ligands in the environment: Geochemistry: Exploration, Environment, Analysis, 8, 91-101. https://doi. org/10.1144/1467-7873/07-151

Cornwall, H.R., 1966, Nickel deposits of North America: Washington, U.S Department of the Interior, Geological Survey Bulletin 1223, 62p.

Dueñas, H., Duque-Caro, H., 1981, Geología del cuadrángulo F-8, Planeta Rica: Colombia: Boletín Geológico Ingeominas, 24, 1-36
Duque-Caro, H., 1980, Geotectónica y evolución de la Región Noroccidental Colombiana: Boletín Geológico Ingeominas, 23, 4-37.

Eliopoulos, D.G., Economou-Eliopoulos, M., 2000, Geochemical and mineralogical characteristics of $\mathrm{Fe}-\mathrm{Ni}$ - and bauxitic-laterite deposits of Greece: Ore Geology Reviews, 16, 41-58. https://doi.org/10.1016/ s0169-1368 (00)00003-2

European Comission (EG), 2018, Report on Critical Raw Materials and the Circular Economy (online): Brussels, Belgium, available in <ec.europa.eu/commission/ publications/report-critical-raw-materialsand-circular-economy_en>

Farré-De-Pablo, J., Aiglsperger, T., Proenza, J.A., Roqué-Rosell, J., González-Jiménez, J.M., Longo, F., 2017, PGE mobility and PGM neoformation by low-temperature hydrothermal fluids -evidence from uvarovite-bearing chromitites in the Dominican Republic, in Mineral Resources to Discover: Québec, 14th SGA Biennal Meeting, 519-522.

Freyssinet, P., Butt, C.R.M., Morris, R.C., Piantone, P., 2005, Ore-Forming Processes Related to Lateritic Weathering: Economic Geology, 100th Anniversary Volume, 681722. https://doi.org/10.5382/AV100.21

Fuchs, W.A., Rose, A.W., 1974, The geochemical behavior of platinum and palladium in the weathering cycle in the Stillwater Complex, Montana: Economic Geology, 69, 332-346. https://doi.org/10.2113/ gsecongeo.69.3.332

Gammons, G.H., 1996, Experimental investigations of the hydrothermal geochemistry of platinum and palladium: V. Equilibria between platinum metal, $\mathrm{Pt}(\mathrm{II})$, and $\mathrm{Pt}(\mathrm{IV})$ chloride complexes at 25 to $300^{\circ} \mathrm{C}$ : Geochimica et Cosmochimica Acta, 60, 1683-1694. https://doi. org/10.1016/0016-7037(96)00048-8

GEOTEG, Ltda., 2003, Geología de los Cinturones Sinú-San Jacinto - Planchas 50 
Puerto Escondido, 51 Lorica, 59 Mulatos, 60 Canalete, 61 Montería, 69 Necoclí, 70 San Pedro de Urabá, 71 Planeta Rica, 79 Turbo, 80 Tierralta. Escala 1:100.000: Bogotá, INGEOMINAS, Memoria, 225p.

Gleeson, S.A., Butt, C.R.M., Elias, M., 2003, Nickel Laterites: A Review: SEG Newsletter, 54, 12-18.

Gleeson, S.A., Herrington, R.J., Durango, J., Velásquez, C.A., Koll, G., 2004, The Mineralogy and Geochemistry of the Cerro Matoso S.A Ni Laterite Deposit, Montelíbano, Colombia: Economic Geology, 99, 1197-1213. https://doi.org/10.2113/ gsecongeo.99.6.1197

Gómez, J., Montes, N.E., Nivia, A., Diederix, H., 2015, Mapa Geológico de Colombia 2015, Scale 1:1.000.000: Bogotá, Colombia, Servicio Geológico Colombiano, 1 map.

González-Jiménez, J.M., Griffin, W.L., Gervilla, F., Proenza, J.A., O’Reilly, S.Y., Pearson, N.J., 2014, Chromitites in ophiolites: How, where, when, why? Part I. A review and new ideas on the origin and significance of platinum-group minerals: Lithos, 189, 127-139. https://doi. org/10.1016/j.lithos.2013.06.016

González, H., Londoño, A.C., 2001, Mapa Geológico del Departamento de Córdoba: Geología, recursos minerales y amenazas naturales - Memoria Explicativa. Escala 1:250.000: Bogotá, INGEOMINAS, 137p.

Green, T., Peck, D., 2005, Platinum Group Elements Exploration: Economic Considerations and Geological Criteria, in Mungall,J.E., (ed), Exploration for Platinumgroup element deposits: Oulu, Finland, Mineralogical Association of Canada Short Course 35, 247-274.

Guzmán, G., Gómez, E., Serrano, B.E., 2004, Geología de los Cinturones del Sinú, San Jacinto y Borde Occidental del Valle Inferior del Magdalena, Caribe Colombiano. Scale 1:300.000: Bogotá, INGEOMINAS, Memoria Explicativa, 134p.

Holwell, D.A., McDonald, I., 2010, A review of the behaviour of platinum group elements within natural magmatic sulfide ore systems: Platinum Metals Review, 54, 26-36. https:// doi.org/10.1595/147106709x480913

Hoyos, N., Velázquez, C.A., 1996, Análisis del Origen de la Lateritización y Saprolitización del Yacimiento Niquelífero de Cerro Matoso: Medellín, Colombia, Universidad EAFIT, Master Thesis, $99 \mathrm{p}$.

Intituto de Investigación e Información Geocientífica Minero Ambiental y Nuclear, INGEOMINAS; GEOTEC, Ltda., 2003, Geología de los Cinturones Sinú-San Jacinto. Planchas 50 Puerto Escondido, 51 Lorica, 59 Mulatos, 60 Canalete, 61 Montería, 69 Necoclí, 70 San Pedro de Urabá, 71 Planeta Rica, 79 Turbo, 80 Tierralta. Escala 1:100.000: Bogotá, INGEOMINAS, Memoria Explicativa, 225p.

Kerr, A.C., Marriner, G.F., Tarney, J., Nivia, A., Saunders, A.D., Thirlwall, M.F., Sinton, C.W., 1997, Cretaceous Basaltic Terranesin Western Colombia: Elemental, Chronologicaland Sr-Nd Isotopic Constraints on Petrogenesis: Journal of Petrology, 38, 677-702. https:// doi.org/10.1093/petroj/38.6.677

Lazarenkov, V.G., Tikhomirov, I.N., Zhidkov, A.Y., Talovina, I.V., 2005, Platinum group metals and gold in supergene nickel ores of the Moa and Nikaro deposits (Cuba): Lithology and Mineral Resources, 40, 521-527. https:// doi.org/10.1007/s10987-005-0049-1

Leal León, C., 2009, La compañía minera Chocó Pacífico y el auge del platino en Colombia, 1897 - 1930: Historia crítica, 39, 150-164.

Londoño, A.C., González, H., 1997, Geología del Departamento de Córdoba, Scale 1:250.000: Bogotá, Colombia, INGEOMINAS, 1 map.

López-Rendón, J., 1986, Geology, Mineralogy and Geochemistry of the Cerro Matoso Nickeliferous Laterite, Córdoba, Colombia: Fort Collins, Colorado, Colorado State University, Master Thesis, 357 p.

Lusty, P., 2016, Critical metals for hightechnology applications: mineral exploration potential in the north of Ireland, in Young, M.E., (ed), Unearthed: impacts of the 
Tellus surveys of north of Ireland: Dublin, Royal Irish Academy, 101-117. https://doi. org/10.7486/DRI.wp98p0649

Mejía, V.M., Durango, J., 1982, Geología de las lateritas niquelíferas de Cerro Matoso: Revista Universidad Industrial de Santander, Boletín de Geología, 15, 99-116. DOI: $10.18273 / \mathrm{revbol}$

Millward, D., Marriner, G.F., Saunders, A.D., 1984, Cretaceous tholeiitic volcanic rocks from the Western Cordillera of Colombia: Journal of the Geological Society, 141, 847-860. https://doi.org/10.1144/gsjgs.141.5.0847

Ministerio de Minas y Energía, 2012a, Resolución 18-0102 de 30 de Enero 2012 (online): Bogotá, Colombia, available in <suin-juriscol.gov.co/clp/contenidos.dll/ Resolucion $/ 4029604$ ? $\mathrm{fn}=$ document-frame. $\mathrm{htm} \$ \mathrm{f}=$ templates $\$ 3.0>$, visited on October 30th, 2016.

Ministerio de Minas y Energía, 2012b, Resolución 18-0241 de 24 de Febrero 2012 (online): Bogotá, Colombia, available in <suin-juriscol. gov.co/viewDocument.asp?id=4030017>, visited on October 30th, 2016.

Mora, J.A., Oncken, O., Le Breton, E., IbánezMejia, M., Faccenna, G., Veloza, G., Vélez, V., Freitas, M., Mesa, A., 2017, Linking Late Cretaceous to Eocene Tectonostratigraphy of the San Jacinto Fold Belt of NW Colombia With Caribbean Plateau Collision and Flat Subduction: AGU Tectonics, 36, 2599-2629. https://doi.org/10.1002/2017TC004612

Naciones Unidas, 1975, Evaluación de Lateritas Niquelíferas en los Departamentos de Córdoba y Antioquia: Nueva York, informe técnico para el Gobierno de Colombia, 286 p.

Navarro-Ciurana, D., Aiglsperger, T., Proenza, J.A., 2012. PGM and Zircon in Al-Rich Chromitite: New Insights by Applying Hydroseparation Technique: Revista de La Sociedad Española de Mineralogía, 16, 186-187.

Ndjigui, P-D., Bilong, P., 2010, Platinum-group elements in the serpentinite lateritic mantles of the Kongo-Nkamouna ultramafic massif
(Lomié region, South-East Cameroon): Journal of Geochemical Exploration, 107, 63-76. https://doi.org/10.1016/j. gexplo.2010.06.008

Nivia, A., 1996, The Bolivar mafic-ultramafic complex, SW Colombia: the base of an obducted oceanic plateau: Journal of South American Earth Sciences, 9, 59-68. https:// doi.org/10.1016/0895-981 1(96)00027-2

Nivia, A., Marriner, G., Kerr, A., 1996, El Complejo Quebradagrande, una posible Cuenca marginal intracratónica del Cretáceo Inferior en la Cordillera Central de los Andes colombianos (resumen), en VII Congreso Colombiano de Geología: Bogotá, Colombia, INGEOMINAS, 108-123.

O’Driscoll, B., González-Jiménez, J.M., 2016, Petrogenesis of the Platinum-Group Minerals: Reviews in Mineralogy and Geochemistry, 81, 489-578.

Oberthür, T., Melcher, F., 2005, PGE and PGM in the supergene environment: A case study of persistence and redistribution in the main sulfide zone of the Great Dyke, Zimbabwe, in Mungall, J.E., (ed), Exploration for Platinum-group element deposits: Oulu, Finland, Mineralogical Association of Canada Short Course 35, 97-111. https:// doi.org/10.2138/rmg.2016.81.09

Ortiz, F., Gaviria, A., Parra, N., Arango, C., Ramírez, G., 2004, Guías geológicas para la localización de metales preciosos en las ofiolitas del occidente de Colombia, en Pereira, F., Castroviejo, E.S., Ortiz, R., (eds), Complejos ofiolíticos en Iberoamérica. Guías de prospección para metales preciosos: Madrid, PROYEGTO XIII. 1- GYTED, 169-199.

Platina Resources Limited, 2019, Annual Financial Report for the year ended 30 June 2019 (online): Western Australia, available in $<$ platinaresources.com.au/investors/annualreports/>, visited on November 1st, 2019.

Plimer, I.R., Williams, P.A., 1987, New Mechanisms for the Mobilization of the Platinum-Group Elements in the Supergene 
Zone, in Prichard, H.M., Potts, P.J., Bowles, J.F.W., Cribb, S.J., (eds), GEO-PLATINUM 87: London and New York, Elsevier, 83-92.

Proenza, J.A., 2015, Mineralogía y Geoquímica de Ni, Co, EGP, Sc, REE en Yacimientos Lateríticos: Revista de La Sociedad Española de Mineralogía, 20, 3-9.

Proenza, J.A., Castroviejo, R., Escayola, M., Cervilla, F., Paladines, A., De Oliveira, D., Ortiz, F., Pereira, E., Rodríguez-Vega, A., Schalamuk, I., Suita, M., 2004, Principales guías de exploración de metales nobles (elementos del grupo del platino) en complejos ofiolíticos, en Pereira, F., Castroviejo, E.S., Ortiz, R., (eds), Complejos ofiolíticos en Iberoamérica. Guías de prospección para metales preciosos: Madrid, PROYECTO XIII. 1- CYTED, 359-372.

Ramírez, C., Weber, M., Tobón, M., Proenza, J.A., Beltrán-Trivino, A., Pujol-Solà, N., Betancur, S., Duque, J., von Quadt, A., 2019, Evolución tectónica desde el Jurásico Superior al Mioceno en Planeta Rica, Córdoba Aportes a la historia geológica del Caribe (resumen), en XVII Congreso Colombiano de Geología: Santa Marta, Colombia, Sociedad Colombiana de Geología y el Consejo Profesional de Geología, 304-305.

Ramos, V., Aleman, A., 2000, Tectonic evolution of the Andes (abstract), in Cordani, U., Milani, E.Z., Filho, T., Campos, D., (eds), Tectonic evolution of South America. 31st International Geological Congress: Rio de Janeiro, Brazil, 453-480.

Salpéteur, I., Martel-Jantin, B., Rakotomanana, D., 1995, Pt and Pd mobility in ferralitic soils of the West Andriamena area (Madagascar). Evidence of a supergene orogin of some $\mathrm{Pt}$ and Pd minerals: Chronique de La Recherche Miniére, 520, 27-45.

Servicio Geológico Colombiano (SGC), 2011, Áreas con potencial mineral para definir Áreas de Reserva Estratégica del Estado (online): Bogotá, Colombia, available in <srvags.sgc.gov.co/JSviewer/Areas_con_ Potencial_Mineral_Version_2011/>
South32, 2019, Annual Report 2019 (online): Western Australia, available in <south32. net/investors-media/investor-centre/ annual-report-suite>, visited on November 1st, 2019.

Spadea, P., Espinosa, A., 1996, Petrology and chemistry of late Cretaceous volcanic rocks from the southernmost segment of the Western Cordillera of Colombia (South America): Journal of South American Earth Sciences, 9, 79-90. https://doi. org/10.1016/0895-9811(96)00029-6

Spikings, R., Cochrane, R., Villagomez, D., Van der Lelij, R., Vallejo, C., Winkler, W., Beate, B., 2015, The geological history of northwestern South America: From Pangaea to the early collision of the Caribbean Large Igneous Province (290-75 Ma): Gondwana Research, 27, 95-139.

SUMICOL S.A., 2002, Caracterización Mineralógica de los tipos de roca de la laterita niquelífera de Cerro Matoso S.A., Colombia: Sabaneta, Colombia, memoria de investigación para Cerro Matoso S.A, 420 p.

Talovina, I.V., Lazarenkov, V.G., 2001, Distribution and Genesis of Platinum Group Minerals in Nickel Ores of the Sakhara and Elizavet Deposits in the Urals: Lithology and Mineral Resources, 36, 116-122. https:// doi.org/10.1023/a:1004870316406

Tauler, E., Lewis, J.F., Villanova-de-Benavent, C., Aiglsperger, T., Proenza, J.A., Domènech, C., Gallardo, T., Longo, F., Galí, S., 2017, Discovery of Ni-smectite-rich saprolite at Loma Ortega, Falcondo mining district (Dominican Republic): geochemistry and mineralogy of an unusual case of "hybrid hydrous $\mathrm{Mg}$ silicate - clay silicate" type Ni-laterite: Mineralium Deposita, 52, 1011-1030. https://doi.org/10.1007/ s00126-017-0750-8

Toussaint, J.F., 1996, Evolución geológica de Colombia, Cretácico: Medellín, Universidad Nacional de Colombia, 277 p.

Unidad de Planeación Minero Energética (UPME), 2009, El Níquel en Colombia (online): 
Bogotá, Colombia, available in <bdigital. upme.gov.co/jspui/bitstream/001/1015/1/ Upme\%20008.pdf.>

United States Geological Survey (USGS), 2018, Mineral Commodity Summaries 2018 (online): Reston, Virginia, available in <minerals.usgs.gov/minerals/pubs/ mcs/2018/mcs2018.pdf $>$, visited on February 7th, 2018.

Villagómez, D., 2010, Thermochronology, Geochronology and Geochemistry of the Western and Central Cordilleras and Sierra Nevada de Santa Marta, Colombia: The Tectonic Evolution of NW South America:
Genevé, Suisse, Université de Genevé, PhD. Thesis, $142 \mathrm{p}$.

Villanova-de-Benavent, C., Proenza, J.A., Galí, S., García-Casco, A., Tauler, E., Lewis, J.F., Longo, F., 2014, Garnierites and garnierites: textures, mineralogy and geochemistry of garnierites in the Falcondo Ni-laterite deposit, Dominican Republic: Ore Geology Reviews, 58, 91-109. https://doi.org/10.1016/j. oregeorev.2013.10.008

Wilde, A., Edwards, A., Yakubchuk, A., 2003, Unconventional deposits of $\mathrm{Pt}$ and $\mathrm{Pd}$ : a review with implications for exploration: SEG Newsletter, 52, 1-18. 